\title{
The Value of Manufactured Housing Communities: A Dual-Ownership Model
}

\author{
Charles Becker Ashley Yea \\ Duke University Duke University
}

October 15, 2015

ERID Working Paper Number 196

This paper can be downloaded without charge from the Social Science Research Network Electronic Paper Collection:

http://ssrn.com/abstract=2681222

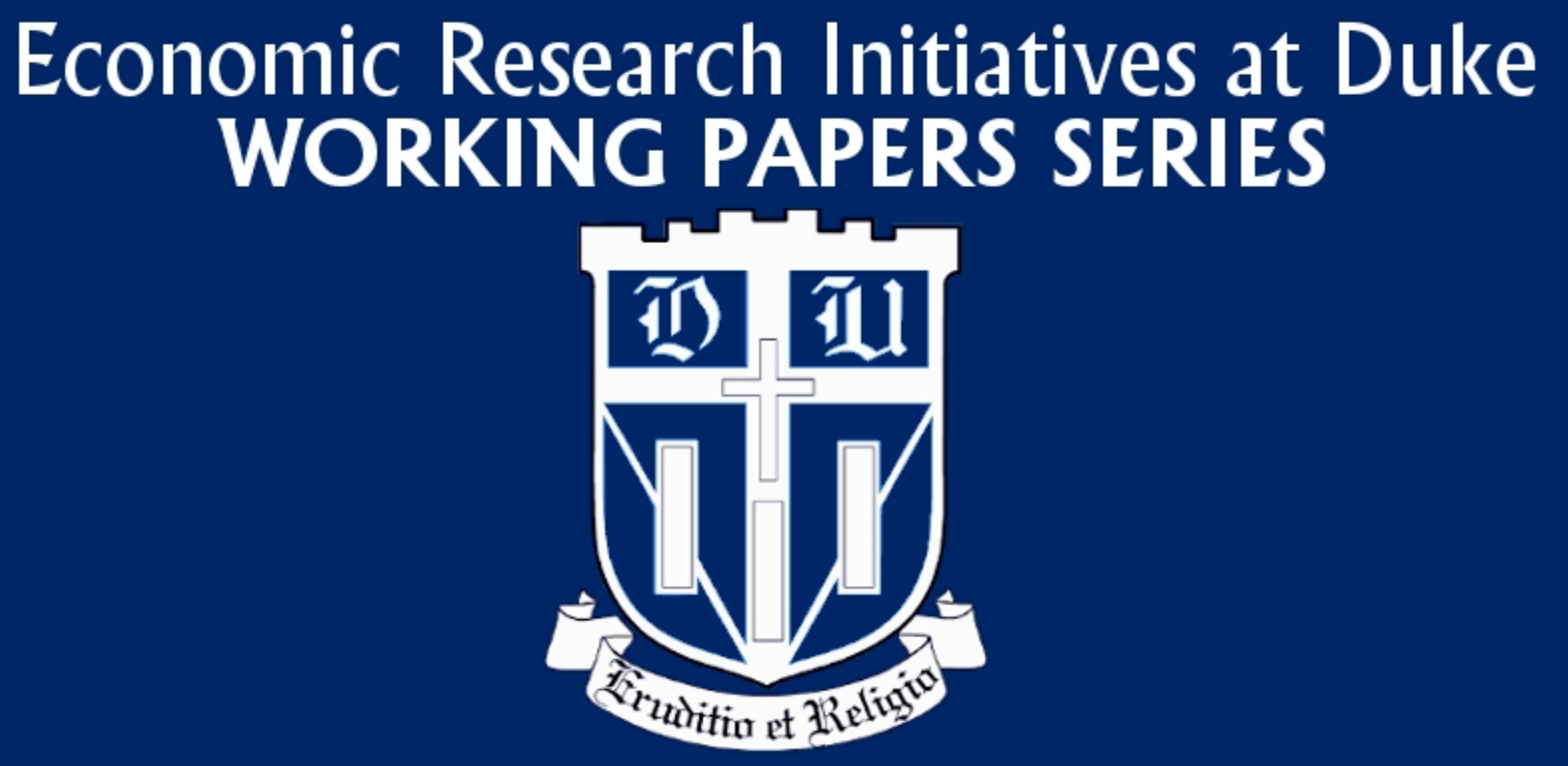




\title{
The Value of Manufactured Housing Communities: A Dual-Ownership Model
}

\author{
Charles Becker and Ashley Yea * \\ Department of Economics, Duke University, \\ 213 Social Sciences Building, Box 90097, Durham, NC 27708, USA
}

\begin{abstract}
There are roughly 50,000 manufactured housing communities (MHCs) in the United States, yet there appears to be virtually no academic research on their asset values. Using a detailed, proprietary database provided by Colliers International, we address this gap. We find that, due to the dual nature of rental and ownership in manufactured housing ownership, MHC values are driven by community rental income and thus affected by median month contract housing rents that surround the community. While value remains affected by traditional factors such as occupancy, location quality, and size of land, it emerges that manufactured housing community sales values are highly sensitive to local rental alternatives. We also find evidence that corporate MHC buyers pay less and sellers receive more for parks relative to smaller "mom-n-pop" owners. ${ }^{1}$
\end{abstract}

\section{Introduction}

There are roughly 50,000 manufactured housing communities (MHCs) in the United States, yet there appears to be virtually no academic research on their asset values. We choose to explore this industry, in large part due to its unique feature of a dual ownership role between owners and renters. We find that in selling and buying manufactured housing communities, park value is independent of structure values on the land. Despite a small literature comparing manufactured housing as a substitute to traditional stick-built housing, we find that manufactured housing is not at all comparable. Rather, manufactured housing community values are driven by local apartment rents.

Home to slightly more than the population of Georgia, North Carolina, or Michigan, MHCs form an important part of the North American housing market, with roughly 3\% of the US population, or about 10.5 million people, living in a manufactured housing community. MHCs are an even more important source of housing for lowermiddle and low-income families, particularly for those who live outside large central cities. Using a detailed,

\footnotetext{
*Corresponding Author; E-mail: ashley.yea@duke.edu.

${ }^{1}$ We would like to thank Chuck Schierbeck and Bruce Nell for the patience, helpfulness, and access to the data. We would thank Jena Happ and Andrew Miles for their invaluable research and GIS help. We would like to thank Caitlin Gorback and Robert Rosenberg for their valuable edits and contributions to the project.
} 
proprietary database provided by Colliers International, we explore the economic nature of MHCs, focusing on the determinants of park asset values and site rents.

A distinctive feature of the large majority of MHCs is that individual tenants own the housing structures (manufactured homes) and pay rent to a park owner who owns the land and provides a selection of infrastructure services. Moreover, tenant-park owner contracts tend to be very short-term, and in many jurisdictions tenant property rights are extremely limited. This arrangement leads to many interesting questions, including: First, why would anyone place a significant fraction of their net worth on someone else's property when doing so surrenders substantial control rights? Next, are park (and MH unit) sales values affected by manufactured housing units (and park) quality measures? Third, do land use restrictions drive up the prices of existing parks by repressing competition? Last, why did the manufactured housing industry collapse in the mid-1990s? The first question is addressed by Gorback (2011) and Becker and Gorback (in progress) in companion papers. Here we address the park sales side of the second question and explore whether it possible to separate values of parks and units. Additional issues addressed involve assessing the impacts of corporate ownership and nearby real estate prices on sales values and rents. The third and fourth questions are the subjects of ongoing research.

Beyond the intrinsic intellectual (and hedonic pricing) interest in the questions we address, the subject is also socially important. MHCs serve a large and in some cases marginalized population with limited housing options. Ironically, given nominally pro-"affordable housing" policy, zoning and park establishment restrictions often ensure that those who live in manufactured housing are systematically excluded from obtaining the same opportunities as traditional homeowners. Sometimes this exclusion is intentional (zoning out the poor); at other times the discrimination is an inadvertent byproduct of policies that favor other forms of housing. Indeed, the impact of broader policies on MHCs is often overlooked, since, while the total number of residents is large, the MHC population is dwarfed by the vastly greater numbers who live on owner-occupied land, or who choose to rent apartments or independent site-built homes instead.

Very recently, there have been new measures to allow MHC homeowners and park owners to access improved funding options through federal programs. However, the interest rate advantage from securing a mortgage for housing on one's own land is so great relative rates for manufactured housing for placement in a park that the 
connection between MHC rents or sales values and local housing price indices is quite weak. Rather, rents and park values appear to be strongly related to county median rent values, suggesting that for most residents the alternative to living in a manufactured housing community would be to rent an independent home or, more likely, live in an apartment. This link between local apartment rents and MHC rents and values is a primary finding of this paper. Not surprisingly, we also find a close link between site rents and community values, but, while location factors are critical, quality of units themselves do not affect park values.

The unique manufactured housing community dataset provided by Colliers International allows us to explore the MHC market in detail. Through a hedonic housing model, we derive and test an equilibrium pricing model that reveals which MHC features are important to investors when purchasing communities. As discussed below, some of the variables included would appear in a conventional hedonic real estate pricing model, but there also are important differences because of the separate ownership of sites and residential structures. In this regard, the model used has more in common with models of commercial and residential rental pricing rather than owneroccupied housing.

\subsection{Background}

The manufactured housing community comprises of approximately 4 million home sites in approximately 50,000 manufactured housing communities. Separated between all-age and retirement communities, roughly half of those communities are located in the southern part of the United States. Of the southern communities, Florida alone contains around 4000 manufactured housing communities. The remaining communities consist of almost 10,000 communities located in the Midwest, 5,000 in the Northeast, and approximately 11,000 in the West.

Manufactured homes are prefabricated homes built off-site, then transported either to the home buyer's private property or to a MHC, where they generally are permanently placed and installed. Despite the potential for a manufactured home being physically capable of being moved again and again, this is rarely observed. In addition to substantial moving costs, structural additions reduce mobility, and factory warranties generally only cover initial placement. We use the term "manufactured house" to refer to those homes that meet the U.S. Department of Housing and Urban Development's Manufactured Housing Program definitions and construction standards. Also known as the HUD code, which went into effect on June 15, 1976, the term "manufactured home" 
specifically refers to housing that meets (or at least once met) the Federal Manufactured Home Construction and Safety Standards. "Mobile homes" refer to prefabricated homes built before the HUD code.

These construction standards lead to the production of good quality housing, despite the low price point of manufactured homes. Manufactured homes are not cheap due to poor quality materials and construction, but rather reflect the volume discounts of raw materials and goods used in the construction of the homes by manufactured home manufacturers, and of course the homogeneity in design that leads to scale economies. Indeed, one would expect contemporary manufactured homes to be better built than many comparable site-built homes because the former must have greater structural soundness in order to withstand the stress of moving and prevent possible damage during transport to their sites. Standardized procedures and corporate liability for construction flaws ensure low variance in the quality of manufactured housing. In contrast, site-built (or "stickbuilt") homes do not need to be built to endure a move, and, as most stick-built owners can confirm, construction quality supervision is more lax on site than it would be in a factory setting. Thus, standardization of assembly also improves quality as does the fact that manufactured housing is built indoors, so that partially constructed units are not exposed to the elements.

There is without question a stigma attached to manufactured housing units. If one uses Google to search "do trailer parks"... the top completed question concludes with "attract tornadoes?" with 3,460 entries as of July 2015. At the same time, visitors to new manufactured housing show rooms are stunned by the range of features and attractiveness of interiors; those who visit modern manufacturing plants cannot but be impressed by the quality of construction, sturdiness, and insulation standards. The obvious reason for these inconsistent impressions is that the stock of manufactured housing is old: 5-6 times as many units/year were built in the 1980s and 1990 s than during the past decade, and so the quality of contemporary units is not representative of the $\mathrm{MH}$ stock. In addition, the MH base of comparison tends to be new starter homes or slightly older middle-class stickbuilt housing. As our empirical findings indicate, this housing is not the appropriate base: a fairer comparison is with aged lower-middle class stick-built housing or with modest (or dilapidated) apartment complexes on the periphery of urban areas.

Due to its factory-assembled and semi-mobile nature, manufactured housing is often classified as a vehicle, 
subject to sales taxes, and when finally situated, subject to local property taxes. This bizarre classification of manufactured housing creates obstacles for potential home buyers. Prospective manufactured home owners who do not simultaneously acquire land find it difficult to secure traditional mortgages, and they are often forced to take out personal property (or "chattel") loans. There are some government programs, such as Federal Housing Administration (FHA) Title I, which help mortgagees lend loans to potential manufactured home owners. This program allows approved FHA lenders to insure loans against defaults and loss from borrowers. Outside of this program, lending options are extremely costly and limited. Many banks do not regard manufactured housing as traditional housing, and thus exclude potential manufactured home owners from taking out traditional mortgages.

On the community side, those who purchase manufactured home communities and current MHC owners are incredibly diverse. Communities are purchased in several different ways: through on-line marketplaces for communities, through property assessors, and via traditional realtors. Owners can range from small mom-andpop singular community operations, to large scale property management groups, to boutique investors who own hundreds of manufactured home communities. Manufactured community buyers rely on sources of internal funding and business loans from banks. As of 2015, Freddie Mac went into the manufactured housing loan business and now offers multi-million dollar loans to professionally managed communities.

Since both landlords and tenants of manufactured housing communities until recently have been much more restricted in purchasing and lending options than those who purchase stick-built housing or develop stick-built communities, we would expect that MHC purchasers' access to finance will be tightly linked to readily projected cash flows, which in turn are dependent on a MHC's rents. Roback (1982) shows that a household's ability to rent housing is directly related to its income. While there are similar rules of thumb for owner-occupied, own-site housing $(\mathrm{OOH})$, the income-OOH purchase price link weakened greatly after 1996, and especially after 2001, until the sub-prime mortgage crisis emerged in 2007. During this period, those who could obtain inexpensive $\mathrm{OOH}$ finance did so; the remainder continued to live in rental housing or MHCs, which therefore should be far closer substitutes than MH and OOH after 1996.

The increased ease of acquiring $\mathrm{OOH}$ can be directly tied to the decline of the manufactured housing industry. The Clinton Administration aggressively sought to expand stick-built home ownership, as did the George W. 
Bush administration, especially following $9 / 11$ when demand in other sectors plummeted. However, since the Colliers database only covers transaction prices from the last five years (2010-2014), we cannot explore the effect of changing US housing policy on manufactured housing community values. Finally, as noted above, it is widely believed within the industry that the common NIMBY-driven restrictions on new park construction are beneficial to existing park owners because competition is restricted. From a theoretical perspective, this is a likely but not inevitable outcome. In any event, the dataset used here is too small to address this issue; Becker and Yea (in progress) do so in a companion paper using a larger but less detailed database.

\section{Literature Review}

Compared to traditional housing economics, very little has been written on the manufactured housing community. However there are a small number of papers regarding manufactured housing and pricing, including Vanderford et al. (2005) and Capozza et al. (2005), both of which focus on home values, and McCarty and Hepworth (2013), which explores determinants of crime. These and other papers on manufactured housing tend to involve straightforward extensions of Rosen's (1974) traditional hedonic model. However, few studies explore park (as opposed to MH home) value; moreover, the potential interdependence between park and home values also means that the estimates are likely biased. For example, consider a hedonic feature that attracts nicer homes (say, less mobile double-wides) for which the park owner can command higher rents. Whether or not the feature is statistically significant in the hedonic regressions will depend on the presence or absence of housing quality measures. Ignoring this housing term may lead to an inappropriate reduced form inference of the variable's value is contingent on attracting nicer homes.

In creating a dual ownership model of manufactured housing communities, Rosen (1974) and Roback (1982) are the best points of departure for understanding the rental property structure. Rosen's (1974) framework links the implicit price of a housing attribute to its marginal valuation to consumers and to firms' marginal cost of attribute production. Manufactured housing communities are one of the few available housing types that feature dual ownership and hence separate markets for sites and structures. This necessitates an equilibrium model to separate the pricing and valuation of land and buildings. This effort also builds on Roback (1982), who shows 
that the value of housing amenities is related to both wage and rent gradients rather than just land values alone. The hedonic approach further emphasizes the need to have a model that separates land and property values to best determine the demand and supply interactions from both sides.

Kaneko et al. (2005) provide an appropriate starting point for the dual asset model we employ. Focusing on apartments in the Tokyo metropolitan area, they set up a competitive equilibrium model that leads to straightforward comparative statics. Kaneko et al. (2005) provide a general model that establishes a landlord-tenant market. However, one of the limitations to this model with manufactured housing communities is that, due to rent subsidies for apartments in the Tokyo metropolitan market, long-term tenants in Tokyo tend to pay less than new tenants.

While Kaneko et al. (2005) is a good start, it must be modified (indeed, simplified) for our purposes because housing unit owners often have no protection from rent increases. Compared to apartment dwellers, site owners are even more restricted in their ability to move when there is an increase in rent due to financial constraints and the structural immobility of their manufactured homes - and few tenants in manufactured housing communities have long term rental contracts. This restriction in mobility also may explain price differences in manufactured housing and apartment rents. Relative immobility means that responses to disequilibrium shocks may be limited in MHCs, albeit for different reasons than in Tokyo. Absence of time series data prevent us from exploring short vs. long run price elasticities - just another interesting MHC topic to be addressed in the future.

Marshall and Marsh (2007) provide one of the few papers that attempts to explain investment demand for manufactured home communities through elasticities of stock demand for new home units. They find that consumers who buy manufactured houses and place them on their own land have lower price elasticities than investors and are much less responsive to price changes. However, their price elasticities assume uniformity of manufactured homes on owner occupied land and manufactured housing communities. Further, they assume that these structures are a substitute for stick-built housing, which appears to be inaccurate in the post-2001 environment for park-placed units. As Shiller (2006) notes, structures themselves do not generally increase in value. Because traditional housing allows for better rate mortgages and certain consumer protections, we cannot expect that traditional stick-built housing or even manufactured housing on owner-occupied property is compa- 
rable to manufactured housing in communities. In addition, price elasticities for investors (park-owners), home purchasers who own property, and home purchasers who locate in parks should differ because the profile and intentions of investors buying a revenue generating property are radically different from home buyers buying a single home for habitation.

Few and Jud (2003) find that apartment buildings can also be valuated through hedonic model techniques. The hedonic apartment pricing literature hypothesizes that complete valuation of these manufactured housing communities is a combination of the present discounted value (PDV) of rental income flows and structure salvage value. Therefore, rental pricing is determined through distance, location, and amenities. Apartment values are determined by rental price, operating expenses, and the cost of capital. In such a model, the value of the apartment building is driven by the PDV of rents. In manufactured housing, since we have both rental (land) and ownership (housing unit) pricing structures, we find that a dual-ownership model works well with the basic structure of apartment valuation estimation. However, since manufactured community residents own their own structures, we modify these valuation factors to reflect this difference.

\section{The Theoretical Dual Ownership Model}

The unique structure of ownership in manufactured communities requires a model of dual ownership of structures and parks. Rather than modeling consumers' asset purchase decisions, we focus on their consumption of structure attributes and location amenities.

\subsection{Demand Side}

Our dual hedonic model of manufactured housing assumes that homogeneous households who purchase manufactured housing seek to maximize the following quasi-concave utility function

$$
U(x, h, p)
$$

subject to the budget constraint of

$$
I=x+q(h, i)+T+r(c, T, I, p)+c
$$

where 
$I=$ annual income

$x=$ non-housing, private good

$h=\left(h_{1}, \ldots, h_{n}\right)$ is a vector of housing attributes, including whether single section, double section, new home, used home

$q(h, i)=$ hedonic manufactured housing unit price function

$T=$ cost of transportation (distance to jobs, shopping, schools)

$p=\left(p_{1}, \ldots, p_{n}\right)=$ vector of park attributes such as sewer systems, amenities, or location amenities

$r(c, T, I, p)=$ hedonic park rents as a pricing function of park attributes

$c=$ cost of moving the actual manufactured housing unit

$i=$ interest rate

Here, the function $r(c, T, I, p)$ represents the cost of park attributes demanded by the tenant. Notice that in the utility function $U(x, h, p)$, households are able to choose $x$ and $h$ and indirectly choose $p$ due to the level of rent tenants are willing to pay given their budget constraints. As communities will be homogeneous for Tiebout reasons, we include $I$ in the $r(c, T, I, p)$ function because community tenants also value higher $I$ neighbors. wealthier neighbors in turn generate positive externalities though greater increases in human and social capital and, because of higher overall demand, generates higher rents. Park attribute rents are not independent since they are linked by tenants' budget constraints. However, they reflect value for different attributes that affect utility, and hence the value of a site manufactured housing unit ascertains two distinct costs, designated as unit price functions, $q(h, i)$ and $r(c, T, I, p)$. This is due to the dual price system of manufactured homes communities where households own their homes and rent the lot of land along with the right to participate in the community separately.

The budget constraint can be rewritten as

$$
I-x \geq T+c+q(h, i)+r(c, T, I, p)
$$

Holding $I, i, x$, and $c$ constant, and treating $r$ parametrically, note that $\frac{\partial r}{\partial T}<0$ and also, for plausible values of $r(c, T, I, p), \frac{\partial h}{\partial T}>0$. That is, rent must be lower and MH housing quality will be greater in more remote places, 
holding income and other terms constant.

We must specify two different but related price functions, $q(h, i)$ and $r(c, T, I, p)$. Housing (park) amenities chosen depend on park (housing) amenities only indirectly through the budget constraint. While rents could possibly vary in the same park, we abstract from this possibility as intra-park rent differences generally are not observable. It is also a standard Tiebout result that all tenants in a given community should be effectively identical.

Let us solve the tenant's (structure owner's) utility maximization and choice problem. We start by setting up the Lagrangian expression:

$$
\mathcal{L}_{\{x, h, p, \lambda\}}=U(x, h, p)+\lambda(I-x-q(h, i)-T-r(c, T, I, p)-c)
$$

Assuming an interior solution, the first order conditions are

$$
\begin{gathered}
\frac{\partial \mathcal{L}}{\partial x}=U_{x}(x, h, p)-\lambda=0 \\
\frac{\partial \mathcal{L}}{\partial h}=U_{h}(x, h, p)-\lambda\left(q_{h}(h, i)\right)=0 \\
\frac{\partial \mathcal{L}}{\partial p}=U_{p}(x, h, p)-\lambda(r(c, T, I, p))=0 \\
\frac{\partial \mathcal{L}}{\partial \lambda}=I-x-q(h, i)-T-r(c, T, I, p)-c=0
\end{gathered}
$$

First order conditions, (9) and (10) imply that the optimal allocation of income between structure quality and park quality must equal the marginal rate of substitution. More precisely, the marginal valuation of an additional dollar spent on a unit of housing must equal the marginal valuation of park quality-the added utility from finding a park that provides a dollar more of amenities:

$$
\frac{U_{h}(x, h, p)}{q_{h}(h, i)}=U_{x}(x, h, p)=\frac{U_{p}(x, h, p)}{r(c, T, I, p)}
$$




$$
\begin{gathered}
\frac{U_{h}(x, h, p)}{U_{x}(x, h, p)}=q_{h}(h, i) \\
\frac{U_{p}(x, h, p)}{U_{x}(x, h, p)}=r(c, T, I, p)
\end{gathered}
$$

Empirically, our individual tenant demand is shown as follows. We have three goods: $x, h$, and $p$. The price of $x$ is normalized to one. The two variables that we focus on are the housing attributes, $h$, and park attributes, $p$. Solving the first order optimization conditions (5)-(8) leads to demand expressions, with these two variables depending on the following factors, where $q$ and $r$ are themselves functions:

$$
\begin{aligned}
& h^{*}=h^{*}(q, r, I, T, c) \\
& p^{*}=p^{*}(q, r, I, T, c)
\end{aligned}
$$

Assuming that $h^{*}$ and $p^{*}$ are normal goods and that utility functions are quasi-concave, in equilibrium, $\frac{\partial h *}{\partial q} \leq 0, \frac{\partial h *}{\partial I} \geq 0, \frac{\partial p *}{\partial r} \leq 0$, and $\frac{\partial p *}{\partial I} \geq 0$. Inverting (12), we can write a tenant's willingness to pay function $r^{*}$ as

$$
r^{*}=\hat{p}(p, q, I, T, c)
$$

Substituting $q(h, i)=q$ and (11) and collecting terms, we have

$$
r^{*}=\widetilde{p}(p, i, I, T, c)
$$

If we let $m$ represent household $m=1, \ldots, M$ and $l$ represent location $l=1, \ldots, L$, then as a log linear approximation, and regarding the marginal cost of structures are fixed at $q_{m, l}$, as estimating equations we have the following hedonic equations with coefficients

$$
\begin{gathered}
h_{m, l}=\alpha_{0}+\alpha_{1} q_{m l}+\alpha_{2} r_{m l}+\alpha_{3} I_{m}+\alpha_{4} T_{l}+\alpha_{5} c_{l}+\varepsilon_{m l}^{h} \\
r_{m, l}=\beta_{0}+\beta_{1} i_{m l}+\beta_{2} p_{m l}+\beta_{3} I_{m}+\beta_{4} T_{l}+\beta_{5} c_{l}+\varepsilon_{m l}^{p}
\end{gathered}
$$


where error term correlation $\rho\left(\varepsilon_{m l}^{h}, \varepsilon_{m l}^{r}\right) \neq 0$ and, ideally, the two equations should be estimated simultaneously. Unfortunately, our data set does not contain $h_{m, l}$ data, leading to potential biases in estimation. The market willingness to pay in location $l$ is the envelope of individual demands.

$$
r_{m, l}=\max _{m}\left(\beta_{0}+\beta_{1} i_{m l}+\beta_{2} p_{m l}+\beta_{3} I_{m}+\beta_{4} T_{l}+\beta_{5} c_{l}+\varepsilon_{m l}^{p}\right)
$$

This equilibrium demand rent hedonic equation then must be estimated jointly with a supply or park valuation function. The two equations and their error terms are interdependent; we estimate them jointly using three stage least squares (3SLS).

\subsection{Supply Side}

The supply side is characterized by two features: park attributes and number of park spaces. Note that the rational park owner will incorporate information about tenants' demand curves (18) into his own optimization problem.

Therefore, the park owner's profit maximization problem is characterized as

$$
\pi\{\sigma *, p *\}=\max _{\sigma, p} r(c, T, I, i, p, \tau) \cdot \sigma-p-i k(\sigma, \tau, p, w)-w l(\sigma, p, w)
$$

where

$p \cdot r(c, T, I, i, p, \tau)=$ hedonic park rents as a pricing function of park attributes

$k(\sigma, \tau, p, w)=$ capital demand as a function of spaces, taxes, park attributes, and wages

$l(\sigma, p, w)=$ labor demand as a function of spaces, taxes, park attributes, and wages (substitution effect)

$\tau=$ property taxes and costs due to zoning restrictions

$\sigma=$ manufactured home community spaces

$p=$ park attributes

$i=$ interest rate

$w=$ wage/cost of labor

Notice that with the dual ownership model, the park attributes' function and willingness to pay appears in both the household utility function and the park owner's profit maximization problem. Park owners consider the 
tenants' demand functions, and charge accordingly, incorporating hedonic park site and structure functions. Park owners can only choose attributes and the supply of units:

$$
\begin{aligned}
& p_{s}^{*}(i, w, \tau, c, T, I) \\
& \sigma_{s}^{*}(i, w, \tau, c, T, I)
\end{aligned}
$$

Substituting equations (20) and (21) into equation (19) and thereby incorporating site renters' preferences into park owner behavioral decisions, yields the community owner profit function:

$$
\begin{gathered}
\pi(i, w, \tau, c, T, I)=\max r(c, T, I, i, \tau, p) \cdot \sigma_{s}^{*}(i, w, \tau, c, T, I) \cdot p^{*}(i, w, \tau, c, T, I) \\
-i k\left(\sigma_{s}^{*}(i, w, \tau, c, T, I), \tau, p_{s}^{*}(i, w, \tau, c, T, I), w\right)-w l\left(\sigma_{s}^{*}(i, w, \tau, c, T, I), p_{s}^{*}(i, w, \tau, c, T, I), w\right)
\end{gathered}
$$

Both park rents and spaces affect profits but ultimately they depend on various cost and demand parameters. Park owners choose $\sigma$ and $r$. We can then generate modified supply functions like (20) and (21) that in equilibrium, must equal demands in (23) and (24).

In equilibrium $p, \sigma$ and $r$ are functions in equilibrium of all exogenous supply and demand variables. In addition,

$$
h^{e}(i, w, \tau, c, T, I)=\sum_{\gamma}^{\Gamma} h^{d}=\sum_{\varphi}^{\Phi} \sigma^{s}
$$

where $r$ is the set of of potential tenants, $\varphi$ is the set of parks, and

$$
p^{e}(i, w, \tau, c, T, I)=p^{d}=p^{s}
$$

A shift reflecting increased demand for park amenities will lead to an increase in rent, while a shift down should lower rents and decreased park quality. Assuming profit function convexity and that MHC residence is a normal good (which may be a strong assumption for some groups), then rents and sales prices will be increasing in residents' incomes. Similarly, increasing costs will lead to reduced park sales prices.

\section{Data}

Details of park characteristics, sales prices, year built, and other features were taken from Colliers International Valuation Advisory Services (CIVAS) manufactured community appraisal data. CIVAS is an internationally 
prominent company that specializes in a comprehensive real property valuation. Spanning a diverse range of geographies and distinct property profiles, their multiple offices allow them expansive coverage of all varieties of property valuation, and in particular, manufactured housing. Their data relate to park owners or banks that need appraisal services whether they are related to sales, tax purposes, or foreclosure.

The proprietary data set provided by CIVAS focuses on the supply side of MHCs. As such, we focus on analyzing factors that affect the operating cost and attractiveness of whole manufactured home communities rather than individual tenant spaces. While there are multiple sources of data for manufactured housing, to our knowledge, the Colliers dataset is the most detailed and highest quality set available for analysis of MHCs. The original data were used in conventional park valuation assessments by Colliers (indeed, a fun exercise is to run regressions of actual park sales prices on Colliers' assessed values; it is also possible to reverse engineer their own assessment model but, obviously, we will not do so); Colliers professionals also were extremely helpful in interpreting their variables and measurements. Larger data sets exist but lack the richness of detail provided in the Colliers data and do not enable us to properly categorize all aspects of the investments made by the manufactured home community.

The CIVAS dataset spans the entire United States region with the majority of points coming from the West, with equal numbers in the Midwest and South, and the fewest in the Northeast. We create several regional dummy variables, notably for California and Florida, to distinguish the effects of differing regions. The observations span from January 2010 to July 2014. This narrow time span is advantageous in that external macroeconomic conditions varied little; on the other hand, the analysis may paint a picture quite different from that which would have prevailed in the heyday of the early 1990s or during the housing boom of the early 2000s.

Our data contain 499 entries of individual manufactured home communities. Several descriptive measures and rating systems have been created by CIVAS itself and are used to evaluate and report certain qualities in the manufactured home parks. Collier's rating systems are included on all appraisal reports to its clients. Thus, their clients are aware of these rating systems. The appraisal pricing algorithm has not been disclosed to us. The dependent variables are recorded park sales price and park rental income, though, as noted, we also have CIVAS assessed value estimates. 
Distance variables consisting of nearest distance to major roads, schools, hospitals, shopping centers, and cemeteries (as an indicator of remoteness) are provided by the 2013 ESRI Data and Maps GIS Layer. We use geographic information systems software to map all 499 points to the nearest straight line distance to major roads, schools, hospitals, and cemeteries to determine the effect of location attributes on MHC transaction price.

Socioeconomic and population variables covering income, education, race, and home value are compiled from Brown University's Longitudinal Tract Data Base, taken from the United States 2010 Census information. This dataset augments our original data set by tract and county level.

\subsection{Variables}

We have separated out the variables into four subcategories to bring clarity to the sheer number of variables considered. A complete overview and descriptive statistics are provided in Table 1 and 2 below.

\subsubsection{Endogenous Variables}

The regressions that follow explore determinants of three endogenous variables. The variable of greatest interest involves transaction price. However, a reduced form regression will not reveal the pathway to determining park value: from an accounting perspective, one may also view transaction price as depending on rental income (or unit rental rates), vacancy rates, and operating costs. Formally, we would expect transaction price to equal the present discounted value of park rents net of operating costs, plus capital gains due to land value appreciation.

Thus, in addition to estimating $\mathrm{MH}$ park sales price, we also estimate a flow value: rent income is defined as annual revenue generated by a given MHC. This income includes rental fees for the land occupied by manufactured houses plus any utilities, maintenance, and other separate miscellaneous amenity costs that are added to the lease cost. Rent income also includes any security deposits, amounts for canceling a lease, and any rents paid in advance. As discussed in the modeling section, rents may be thought of as an inverse demand function that reflects willingness to pay on the part of tenants.

In setting rents, conditional on demand characteristics and costs of amenities provided, the rational park owner behaves as a monopolist in the sense that s/he will take into account prospective tenants' demand curves. If demand is perfectly elastic (the elasticity of substitution between living in a given MHC and in an alternative 
Table 1: Complete Descriptive Statistics

\begin{tabular}{|c|c|c|c|c|c|}
\hline Variable & $\mathrm{N}$ & Mean & St. Dev. & Min & Max \\
\hline \multicolumn{6}{|l|}{ Dependent Variables } \\
\hline Transaction Price (1000's) & 491 & 5600 & 7900 & 0 & 61000 \\
\hline Rent Income (1000’s) & 483 & 430 & 700 & 0 & 5400 \\
\hline \multicolumn{6}{|l|}{ Parameters } \\
\hline Density & 485 & 11.09 & 79.28 & .7 & 1750 \\
\hline Occupancy (\%) & 381 & 85.82 & 20.61 & 0 & 100 \\
\hline Vacancy $(\%)$ & 483 & .05 & .09 & 0 & .73 \\
\hline \multicolumn{6}{|l|}{ Features } \\
\hline Appeal & 487 & 2.23 & .90 & 0 & 6 \\
\hline Cemeteries (In distance) & 499 & .033 & .037 & 0 & .283 \\
\hline Condition & 487 & 2.23 & .94 & 0 & 6 \\
\hline Double Section & 491 & 54.42 & 106.05 & 0 & 814 \\
\hline Hospitals (In distance) & 499 & .082 & .136 & 0 & 1.489 \\
\hline Location Quality & 492 & 2.24 & .83 & 0 & 6 \\
\hline Number of Units & 486 & 160.11 & 179.1 & 7 & 1814 \\
\hline Parking & 417 & 1.47 & .99 & 0 & 5 \\
\hline Project Amenities & 248 & .37 & .48 & 0 & 1 \\
\hline Quality & 487 & 2.13 & .95 & 0 & 6 \\
\hline Resident Type & 477 & .16 & .37 & 0 & 1 \\
\hline Major Roads (In distance) & 499 & .002 & .004 & 0 & .0334 \\
\hline Schools (In distance) & 499 & .014 & .016 & 0 & .177 \\
\hline Security Features & 200 & 1.21 & 1.39 & 0 & 4 \\
\hline Single Section & 491 & 94.78 & 130.94 & 0 & 1266 \\
\hline Size (acres) & 491 & 35.51 & 123.14 & .02 & 2631 \\
\hline Triple Section & 491 & 1.20 & 20.19 & 0 & 441 \\
\hline Year Built & 499 & 1972 & 16.14 & 1910 & 2014 \\
\hline \multicolumn{6}{|l|}{ Income and Education } \\
\hline High School or less (In value) & 466 & 7.043 & .630 & 3.989 & 8.470 \\
\hline 4-Year College Degree (In value) & 465 & 5.977 & .977 & 2.890 & 8.540 \\
\hline Unemployed (ln value) & 465 & 5.001 & .708 & 2.485 & 6.648 \\
\hline Median Household Income (ln value) & 466 & 10.637 & .445 & 8.794 & 11.833 \\
\hline Persons in Poverty (ln value) & 464 & 6.260 & .833 & 3.135 & 8.360 \\
\hline \multicolumn{6}{|l|}{ Housing Values } \\
\hline Median Monthly Contract Rent (ln value per county) & 462 & 6.372 & .495 & 4.883 & 7.601 \\
\hline Median Home Value (In value per county) & 463 & 11.853 & .742 & 9.622 & 13.816 \\
\hline
\end{tabular}


Table 2: Complete Descriptive Statistics-continued

\begin{tabular}{|c|c|c|c|c|c|}
\hline Variable & $\mathrm{N}$ & Mean & St. Dev. & Min & Max \\
\hline \multicolumn{6}{|l|}{ Geographical Factors } \\
\hline \multicolumn{6}{|l|}{ Region dummies } \\
\hline Northeast & 499 & .1122 & .3160 & 0 & 1 \\
\hline Midwest & 499 & .2665 & .4426 & 0 & 1 \\
\hline South & 499 & .2244 & .4176 & 0 & 1 \\
\hline West & 499 & .3968 & .4897 & 0 & 1 \\
\hline \multicolumn{6}{|l|}{ Topography } \\
\hline Level & 442 & .8801 & .3252 & 0 & 1 \\
\hline Sloping & 442 & .0656 & .2479 & 0 & 1 \\
\hline Rolling & 442 & .0317 & .1753 & 0 & 1 \\
\hline Hilly & 442 & .0204 & .1414 & 0 & 1 \\
\hline Steep & 442 & .0023 & .0476 & 0 & 1 \\
\hline \multicolumn{6}{|l|}{ Features } \\
\hline \multicolumn{6}{|l|}{ Rights Transferred } \\
\hline Fee Simple & 425 & .9412 & .2356 & 0 & 1 \\
\hline Leased Fee & 425 & .0518 & .2218 & 0 & 1 \\
\hline Leasehold & 425 & .0071 & .0838 & 0 & 1 \\
\hline \multicolumn{6}{|l|}{ Transaction Status } \\
\hline Expired Listing & 492 & .0081 & .0899 & 0 & 1 \\
\hline Fell Out of Escrow & 492 & .0703 & .4211 & 0 & 1 \\
\hline In Contract & 492 & .0142 & .1185 & 0 & 1 \\
\hline Listing & 492 & .1646 & .3712 & 0 & 1 \\
\hline Offer/Pending & 492 & .0427 & .2023 & 0 & 1 \\
\hline \multicolumn{6}{|l|}{ Utilities } \\
\hline Water & 194 & .0103 & .1013 & 0 & 1 \\
\hline Sewer & 194 & .0361 & .1870 & 0 & 1 \\
\hline Trash & 194 & .2165 & .4130 & 0 & 1 \\
\hline Cable & 194 & .0103 & .1013 & 0 & 1 \\
\hline Combination of two of cable, sewer, trash, or water & 194 & .2113 & .4093 & 0 & 1 \\
\hline Water, Sewer, Trash & 194 & .4845 & .5011 & 0 & 1 \\
\hline Water, Sewer, Trash, Cable & 194 & .0309 & .1736 & 0 & 1 \\
\hline
\end{tabular}


dwelling is infinitely large), then the park owner is in effect a price taker, and only local housing market conditions will affect rents. But if, as is likely the case, alternative housing is not a perfect substitute, then the park owner will take advantage of market power and charge rents that capture additional consumer surplus.

If all residents are identical, or if the park owner is unable to behave as a perfectly discriminating monopolist who charges different prices to different tenants according to their assessed willingness to pay, then a rational park owner may charge a rate at which there is excess supply of spaces. In this case, the occupancy rate also will be endogenous, and is worth exploring independently of its effect on rental income.

Beyond the simple, static equilibrium profit maximization model described above, the occupancy rate also serves as a complex signal in a disequilibrium or dynamic framework both to prospective tenants and $\mathrm{MH}$ park buyers, both of whom are trying to determine whether the vacancies can possibly be filled. High vacancy in an established park may signal management or resident problems to tenants and declining demand to prospective owners. In older parks, vacancies may be accompanied by abandoned MH units that are at best an eyesore and at worst hazardous; in either case, prospective owners may factor in likely removal costs.

\subsubsection{Exogenous: Location Characteristics}

Location quality describes how close are these communities to amenities such as shopping centers, major attractions, and nearest city centers. Manufactured housing communities with higher location quality may also be close to major highways, good schools, and close to shopping amenities. We estimate location quality through Colliers' five star rating system: one star for the worst location quality, five stars for the best location quality. As noted above, we also have geo-coded estimates of distance to major amenities.

\subsubsection{Exogenous: Market Characteristics}

Occupancy-As noted above, this is in principle an endogenous demand measure, but, as is discussed below, in practice we are unable to estimate it simultaneously, and therefore treat it as exogenous in the MHC price and park rent equations.

Resident types are classified on whether a manufactured home community is an all-age community or a 55 years or older community. If entry or conversion of park restrictions are unrestricted, then competitive forces should drive out differences in profitability, and hence resident restrictions should not affect sales value (espe- 
cially as new owners can change rules) or rental income. We include a residential type variable as a test of the efficient markets hypothesis (or as an indicator of unobserved heterogeneity in market conditions); empirically, it turns out that residential type does not tend to affect the endogenous terms.

\subsubsection{Park Quality Variables}

While obviously subjective, the Colliers park appeal rating measure (an interval categorical variable ranging from fair to fair/average, average, average/good, good, good/excellent, and excellent) may give a useful, visceral reaction to the MHC and its surroundings. As anyone who has visited large numbers of parks or perused an online listing service like www.mhvillage.com can attest, parks with nearly identical descriptions may elicit wildly divergent reactions from prospective tenants and owners. In essence, use of an appeal measure is likely to reduce unobserved heterogeneity that, if not controlled for, could give rise to omitted variables' bias.

A similarly subjective term is Colliers' community condition measure (again, an interval categorical variable ranging from fair to fair/average, average, average/good, good, good/excellent, and excellent). In addition to being included for reasons similar to park appeal, the condition term provides an indicator of past infrastructure investments and maintenance efforts.

Double wide or double section homes are MH homes that are comprised of two single section units. Their presence in a park is revealing in several respects. First, double-wides occupy more space and therefore typically pay higher site fees. Second, since housing space is a normal good, and since similar-vintage double wides are worth more than single-wides, double-wide tenants tend to be wealthier. To the extent that being surrounded by higher socioeconomic status neighbors is a positive externality, the park owner should be able to capture some of those benefits via generally higher site rents. Double-wides are also more expensive to move than single-wides, so that double-wide residents will have less elastic demand curves, and park owners can exploit this by charging higher rents. Whether or not they actually do charge higher rents is an empirical matter: park owners should want to attract double-wide residents as well, and so may offer discounts to attract the positive externality. In either case, the presence of double-wides should increase park value.

Number of units is a MHC scale measure that, obviously, should be a major determinant of both sales prices and rental income. An ideal dataset also would record the potential number of units; unfortunately, this 
information is not available. In the long run, this $\sigma$ measure is an endogenous variable in equation (19). However, virtually all of the parks in our sample were built more than a generation earlier: the average age of founding was 1972! It is implausible that parks formed decades earlier would have anticipated current conditions. Furthermore, the vast rise in zoning stringency has greatly curbed most endogenous responses. Hence, for estimation purposes we treat the number of units as exogenous.

We include six permutations of three options of driveway, street, and garage to categorize parking. For simplicity, we rank the options and create a single measure. Based on discussions with CIVAS professionals, we rate garage parking as most valuable, followed by a paved personal driveway, and then street parking. We do not have road quality information; however, higher quality communities tend to have paved roads while lower quality communities tend to have dirt roads.

Some manufactured housing communities have no clubhouses or amenities. For those that have at least one amenity, we create a single categorical variable project amenities that takes on the values 0,1 , or 2 to indicate the three categories of none, basic, or deluxe amenities. A MHC is defined as having "basic amenities" if it has at least one and not more than two of the following basic community amenities: clubhouse, on-site leasing, manager's offices, and/or a singular community amenity such as a basketball court, playground, recreation area, pool, or laundry.

A MHC is defined as having deluxe amenities if it has $3+$ community amenities. These communities are often characterized by multiple clubhouses, nice landscaping, and community activity centers. These are generally highly rated communities. In addition to the basic amenities listed, examples of sports amenities found in wellprovisioned communities includes general exercise/fitness facilities, shuffleboard courts, fishing pond/fishing pier, tennis courts, horseshoes, baseball field/diamond, soccer field, billiards, Bocce ball, golf course, putting greens, golf prop shop, volleyball courts, sauna, heated swimming pools, and organized activities and events. Environment/Outdoor amenities in the CIVAS dataset include: lakes, green space, walking trail, marina, pet park, duck pond, gazebo, beach, crabbing pier, gated main entrance with key card entry, nature preserve, covered picnic area(s), picnic area with outdoor grills, picnic shelter, and a lakefront sundeck. Additional indoor amenities include: library, community room/building, on-site leasing office, storm shelter, spa, restaurant, big 
screen television, business center, computer center, library/reading room, kitchen, and craft room. Finally, storage amenities include: RV storage/parking, RV parking, boat storage, boat docks/ramps, boat slips, boat launch ramp, and storage lockers. Obviously, any given MHC will only have a modest subset of these amenities, and those they do have will be customized to the location, but it should be apparent that there is a vast range across parks, from many with no facilities whatsoever to others with an impressive set of (upper) middle-class amenities.

In general, MHCs with age restrictions, and especially those in Florida, typically contain more amenities, as these manufactured home communities tend to either be a resort-type, retirement, or a combination of both communities. The modest sample size and idiosyncratic nature of many amenities makes it impossible to estimate the return to each attribute. Rather, we note that communities rated average or lower by CIVAS either with the star rating (3 stars or less) or letter rating (B-C) tended to have only 1-2 amenities. Those that received a rated higher star rating ( 3 stars or more) or letter rating (A-B) tended to on average have 3 or more amenities. Thus, we compress the amenity variable, note that it is highly collinear with the CIVAS rating, and in practice use only one of the two terms in the regression analysis.

However, we do separate out security features from other amenities as they may matter in different ways and have different interaction effects. We create a categorical variable that takes on a value from 0-6 depending on the level of increasing security found in the community. While it would have been desirable to measure both the effects of criminal and physical safety precautions in the community, the security features variable just measures physical features rather than the security features of tenants, such as background and criminal checks. Basic security features include street lights, perimeter fences, and security patrol. "Increased security features" are defined as parks that have two or more of the following: guarded gate, perimeter fence, security patrol, street lights, gate, and river border.

We have chosen to include one interaction variable that interacts security features with resident type. We do not include any other interaction terms because they only marginally affected the other coefficients.

Finally, topography refers to the layout of the land. We generate five dummy variables that categorize the layout of a given piece of land. These dummies are level, sloping, rolling, hilly, and steep. Utilities describes whether residents will have water, sewer, trash, or cable services. There can be any combination of these; 
however, more is better. These utilities may be private or public systems. Year built describes the age of the manufactured home community. As seen in Table 1, the dataset includes communities whose founding year ranges from 1910 to 2014, but the vast majority were founded one or more generations before the date of sale in this dataset.

\section{Empirical Analysis}

The dual ownership model describes a system of ownership where the tenants own a single asset, the manufactured home, and the community owner rents out the land upon which the manufactured home will be placed. As mentioned in both Rosen (1974) and Roback (1982), this model ultimately should be analyzed from both the household and the community owner's side to effectively characterize equilibrium in a land and property separation model. Since our current data set includes only detailed supply side data, we are obliged to follow a more restricted path. In essence, there are two possible estimation approaches. The first, recognizing the simultaneous determination of all endogenous variables, would be to estimate a system of equations using three-stage-least squares (3SLS), and including only truly exogenous terms as regressors. 3SLS will allow us to combine both a simultaneous equations and generalized least squares approach to produce consistent estimates and explain the correlation structure in disturbances across different equations. Because of the simultaneous nature of our empirical equations, the error terms will be correlated, and thus by estimating multiple equations together under one 3SLS system will provide an efficiency gain and also will correct for endogeneity. Alternatively, we could regard decisions as being made sequentially, and also recognize that some variables are likely to be driven more by short-run shocks, especially given the nature of the US housing market over the past decade. In light of initial estimates, this turns out to be our preferred approach with respect to occupancy rate. While we began by modeling occupancy as being driven by levels and changes in local (county) economic conditions, these turned out to be consistently insignificant, and we concluded that occupancy rates are largely driven by idiosyncratic risk. Therefore, we begin this multi-tiered system to rents and park value with occupancy regressions provided in the Appendix. We proceed recursively, treating rental income as a function of park attributes, location attributes, and vacancy rate and occupancy. This, in effect, involves estimating equation (16) while treating park attributes 
as exogenous. Finally, we model park sales price (in effect, profit function equation (22)) as a function of rental income and local housing market conditions and estimate it together with rental income.

Although we have two main hedonic regressions, because we are mainly focused on the asset value of the manufactured community model, we assume that tenants within each community pay identical rent rates. This enables us to identify an equilibrium hedonic function $r(c, T, p, I)$ as it appears in both the household demand and park supply functions. The reduced form estimation is a disadvantage, but we cannot identify structural demand and supply parameters separately without imposing restrictions - in essence, those that allow us to estimate the model recursively, plus the assumption of independence of demand and supply parameters. Specifically, we need to assume that the terms that determine rental income only affect demand and that their presence in a park is random, rather than reflecting unobserved heterogeneity in costs of provision. Our first approximation to addressing this problem is to include dummy variables for Florida, California, Arizona, and retirement (age 55+ restricted) communities.

Through creating separate hedonic regressions for both transaction price and rental income, we are able to separate the variables and find which factors are important to park owners and tenants. This is significant because these two populations have control over different things, as seen in their different optimization problems.

In short, there are major identification problems that cannot truly be overcome with a static dataset. The absence of multiple sales means that a differences-in-differences model cannot be estimated; unobserved heterogeneity with omitted terms that are likely correlated with included regressors limits our confidence in the parameters obtained. Fortunately, some of the terms are likely to suffer fewer identification problems than others, and these are the ones emphasized in the following discussion.

Other than for binary variables, a log-linear model is better suited for analysis due to the great variability regarding the range of community scale and portfolio sizes. This wide range of observations makes homoskedasticity unlikely. A log-linear model also offers ready interpretation and has the intuitive appeal of not assuming identical marginal effects in tiny mom-and-pop and large corporate MHCs.

We use multiple imputation methods to compensate for missing data. Rubin (1987), Rubin (1996), and Schafer and Graham (2002) provide both details on and justification for the multiple imputation procedures 
followed. We use a log linear multiple imputation regression to best estimate our data. Since most variables in the data set contain some missing observations, when regressed together, we lose more than half of our observations without imputation. As a result, we utilize multiple imputation to maintain a reasonable set size. While Rubin (1987) shows that even with $50 \%$ missing data, $m=10$, where $m$ represents the number of set of imputed values, is equal to $95 \%$ efficiency, Schafer and Graham find that $m=20$ provides even more noise reduction. With the current quickness of the state of technology, we choose 50 iterations due to our fairly high percentage of missing observations and because computational time between $m=20$ iterations and $m=50$ is negligible given the small sample size.

While multiple imputation is an accepted method of addressing missing data, we also estimate the model without imputed data. Even when the number of observations is greatly reduced, the coefficients, signs, and in many cases significance remain similar. The results of the original log linear multi-layer 3SLS and OLS estimates are provided in Appendix Table A1.

\subsection{Results}

Our recursive procedure begins by exploring determinants of occupancy rates (Appendix Table A2). As it turns out, the only variables that are even marginally significant are the number of units (with a negative sign) and location quality (positive sign). Park characteristics (including many others in additional regressions not reported), local economic conditions, resident characteristics, and owner characteristics did not matter. Since we were unable to find any variables that effectively explained occupancy variance, estimating it jointly with sales price and park rents would have been fruitless. We conclude that occupancy will depend on economic and real estate market conditions that we do not observe, and therefore treat it as being exogenous in the main regressions.

The next step is a 3SLS hedonic regression for transaction price and rent income. This regression contains two simultaneously estimated equations. The first analyzes those factors that are important to investors when purchasing a property; the second concerns determinants of contract rent. We offer several variations of these regressions to give an indication of the sensitivity of key terms as additional variables are added.

Our results using multiple imputation (Table 3) provide intriguing insights into the major determinants of price for community owners considering a purchase of a manufactured home community. The results of the first 
Table 3: 3SLS Regression Results for Transaction Price and Rent Income as a Dependent Variables (Multiple imputed log price)

\begin{tabular}{|c|c|c|c|}
\hline & (1) & (2) & (3) \\
\hline \multicolumn{4}{|l|}{ Transaction Price } \\
\hline Rent Income & $\begin{array}{c}0.914 * * * \\
(18.89)\end{array}$ & $\begin{array}{c}0.918 * * * \\
(18.09)\end{array}$ & $\begin{array}{c}0.920 * * * \\
(18.14)\end{array}$ \\
\hline Occupancy & $\begin{array}{l}0.394 \\
(1.75)\end{array}$ & $\begin{array}{l}0.389 \\
(1.86)\end{array}$ & $\begin{array}{l}0.391 \\
(1.85)\end{array}$ \\
\hline Location Quality & $\begin{array}{l}0.119 * * * \\
(4.12)\end{array}$ & $\begin{array}{l}0.109 * * * \\
(3.87)\end{array}$ & $\begin{array}{l}0.109 * * * \\
(3.93)\end{array}$ \\
\hline Double Section & $\begin{array}{l}0.0682 * * * \\
\quad(5.87)\end{array}$ & $\begin{array}{l}0.0660 * * * \\
(5.45)\end{array}$ & $\begin{array}{l}0.0656^{* * * *} \\
(5.44)\end{array}$ \\
\hline Size (Acres) & $\begin{array}{c}0.0126 \\
(0.38)\end{array}$ & $\begin{array}{c}0.00832 \\
(0.25)\end{array}$ & $\begin{array}{c}0.00674 \\
(0.20)\end{array}$ \\
\hline Median Monthly Contract Rent (county) & & $\begin{array}{c}0.221 * * * \\
(3.43)\end{array}$ & $\begin{array}{c}0.221^{* *} \\
(3.10)\end{array}$ \\
\hline Median Home Value (county) & & $\begin{array}{c}-0.0845^{*} \\
(-2.14)\end{array}$ & $\begin{array}{r}-0.0839 \\
(-1.93)\end{array}$ \\
\hline High School or less & & & $\begin{array}{c}0.00659 \\
(0.17)\end{array}$ \\
\hline 4-Year College Degree & & & $\begin{array}{c}0.00536 \\
(0.14)\end{array}$ \\
\hline Unemployed & & & $\begin{array}{l}0.0107 \\
(0.31)\end{array}$ \\
\hline Median Household Income & & & $\begin{array}{c}-0.0343 \\
(-0.35)\end{array}$ \\
\hline Persons in Poverty & & & $\begin{array}{c}-0.0269 \\
(-0.71)\end{array}$ \\
\hline Constant & $\begin{array}{c}2.222 * * \\
(3.75)\end{array}$ & $\begin{array}{l}1.800^{*} \\
(2.65)\end{array}$ & $\begin{array}{l}2.175 \\
(1.83)\end{array}$ \\
\hline \multicolumn{4}{|l|}{ Rent Income } \\
\hline Location Quality & $\begin{array}{l}0.170 * * * \\
(6.77)\end{array}$ & $\begin{array}{c}0.153 * * * \\
(6.22)\end{array}$ & $\begin{array}{c}0.153^{* * *} \\
(6.21)\end{array}$ \\
\hline Number of Units & $\begin{array}{l}0.974 * * * \\
(30.93)\end{array}$ & $\begin{array}{l}0.995 * * * \\
(31.48)\end{array}$ & $\begin{array}{l}0.995 * * * \\
(31.65)\end{array}$ \\
\hline Resident Type $\times$ Security Features & $\begin{array}{c}-0.0668 \\
(-1.64)\end{array}$ & $\begin{array}{c}-0.0831 \\
(-1.91)\end{array}$ & $\begin{array}{c}-0.0835 \\
(-1.92)\end{array}$ \\
\hline Single Section & $\begin{array}{l}-0.0283 \\
(-1.62)\end{array}$ & $\begin{array}{c}-0.0359 * \\
(-2.10)\end{array}$ & $\begin{array}{c}-0.0360^{*} \\
(-2.11)\end{array}$ \\
\hline Double Section & $\begin{array}{c}0.0517 * * * \\
(3.60)\end{array}$ & $\begin{array}{c}0.0477 * * * \\
(3.55)\end{array}$ & $\begin{array}{c}0.0477 \text { *** } \\
(3.53)\end{array}$ \\
\hline Year Built & & $\begin{array}{c}-0.00517 * * * \\
(-3.89)\end{array}$ & $\begin{array}{c}-0.00517 * * * \\
(-3.88)\end{array}$ \\
\hline Security Features & & $\begin{array}{c}0.0280 \\
(1.12)\end{array}$ & $\begin{array}{c}0.0282 \\
(1.11)\end{array}$ \\
\hline Project Amenities & & $\begin{array}{c}0.00176 \\
(0.03)\end{array}$ & $\begin{array}{c}0.00101 \\
(0.02)\end{array}$ \\
\hline Median Monthly Contract Rent (county) & & $\begin{array}{c}0.134^{*} \\
(2.46)\end{array}$ & $\begin{array}{l}0.134^{*} \\
(2.46)\end{array}$ \\
\hline Median Home Value (county) & & $\begin{array}{c}0.0128 \\
(0.32)\end{array}$ & $\begin{array}{c}0.0129 \\
(0.32)\end{array}$ \\
\hline Constant & $\begin{array}{c}8.052 * * * \\
(72.05)\end{array}$ & $\begin{array}{c}17.20 * * * \\
(6.55)\end{array}$ & $\begin{array}{c}17.19 * * * \\
(6.52)\end{array}$ \\
\hline$N$ & 499 & 499 & 499 \\
\hline $\mathrm{R}^{2}$ & 0.8826 & 0.8875 & 0.8882 \\
\hline Adjusted $\mathrm{R}^{2}$ & 0.8435 & 0.8757 & 0.8758 \\
\hline
\end{tabular}

$t$ statistics in parentheses

$* p<0.05, * * p<0.01, * * * p<0.001$ 
log linear model (Column 1) demonstrate that transaction price of a manufactured community is driven by rental income, occupancy of the manufactured home community, the location quality, and the number of double section homes.

The very high statistical significance (t-value - 18.89) of rent income on transaction price is particularly notable. The coefficient of .914 implies that a doubling of rental income will lead to a near doubling in transaction price. Moreover, the coefficient actually rises slightly as socioeconomic factors are added. This confirms that investors are primarily concerned with income generation as opposed to acquiring property for speculative purposes. While this finding should be transparently obvious to anyone in the industry, the near equi-proportionality is somewhat less obvious.

Independent of rental income, the occupancy rate also has a large effect on MHC sales price. A $10 \%$ increase in occupancy will result in a $3.94 \%$ increase in transaction price. Note that the regression equation already controls for rental income. Consequently, the occupancy variable is picking up other factors: a low occupancy rate might signal a declining economy or impending park problems that reduce its value beyond the immediate effects on reducing rental income.

A unit rise in location quality increases purchase price by $11.9 \%$; this term is stable and strongly significant. Communities that are close to major shopping centers, parks, and other positive location identifiers generally command higher purchase prices.

Communities with greater acreage have the potential to expand, controlling for occupancy and rental income (and hence, in effect, the number of units). While we anticipated that this option would be valuable, in practice it does not appear to be. Most likely, the acreage term is correlated with an unobserved usable space measure. For example, a community may have a larger lot of land, but in reality, much of the land may be unsuitable for additional pads, inaccessible to any roads, or even wetland. Similarly, if the size of the community is large and allows for larger homes, then the effect would be captured in part by the double-section variable. Indeed, this is indeed the case: the elasticity of MHC price with respect to the share of double-wides is nearly 7 percent.

The most striking result is the significance of median county monthly contract rent combined with the median home value insignificance in some regressions, and significantly negative sign in others. A $100 \%$ increase in 
median monthly contract rent results in a $22.1 \%$ increase in transaction price (column 2). Because contract rent is significant and median county home value is negative or insignificant, it is apparent that value is driven by nearby apartment and stand-alone housing rental rates. By implication, rentals are close substitutes for MHP housing; owner-occupied housing is not. ${ }^{2}$ In this case, MHC revenue is driven by nearby rents, even though the vast majority of structures in MHPs are themselves owner-occupied. Manufactured housing, even when placed in parks, has long been compared to stick-built housing as an alternative. It is clear from these regression results that this assumption is wrong. Park-sited manufactured housing is instead more comparable to apartments and manufactured housing communities are comparable to other revenue generating rental properties such as apartment complexes and commercial lease spaces.

Table 4 adds measures of housing unit quality assessment and distance to major amenities. Housing quality is a potentially important variable. If parks and housing units are a tied product, then $\mathrm{MH}$ unit quality will be regarded as an amenity that enhances park sale value. If they are separable products, then park value will be independent of $\mathrm{MH}$ unit quality, and hence value. As it turns out, the results are conclusive: ratings and distance measures do not significantly directly affect MHC sales price. This does not mean that sales price and unit quality are uncorrelated: double-wides are nicer than single wides, and generate higher rents and sales prices; sales price is higher in better-situated locations in more expensive areas, and those who live there will have higher incomes - and hence are likely to purchase nicer units. Rather, we find no causal relation between unit quality and park value.

In addition to quality, as mentioned in the variables section above, Colliers also rates park appeal and community condition in order to provide uniformity when appraising manufactured home communities. These terms should affect MHC value directly, as they indicate neglected maintenance and needed upgrades; they also may affect rents. As it turns out, the regressions in Table 4 provide no evidence that these measures affect sales price directly. Nor do they appear to affect rents in Table 5.

Distance to major roads, distance to hospitals, and distance to cemeteries (proximity may be regarded as a

\footnotetext{
${ }^{2}$ Those with a sense of humor may wonder whether we believe that MHC housing is a complement to owner-occupied housing on owneroccupied plots, as the negative sign implies. We do not. Rather, rising median home values signal growing affluence and hence declining demand for MHC housing. In essence, we believe that MHC housing is an "inferior" good in the sense that, above a modest point, the income elasticity of demand is negative.
} 
Table 4: 3SLS Regression Results for Transaction Price and Rent Income as a Dependent Variables with Distance and Ratings Measures in Transaction Price(Multiple imputed log price)

(1)

(2)

\begin{tabular}{|c|c|c|}
\hline \multicolumn{3}{|l|}{ Transaction Price } \\
\hline Rent Income & $\begin{array}{l}0.917 * * * \\
(13.59)\end{array}$ & $\begin{array}{c}1.005^{* * * *} \\
(21.30)\end{array}$ \\
\hline Occupancy & $\begin{array}{l}0.468 \\
(2.01)\end{array}$ & $\begin{array}{l}0.867 * * * \\
(7.50)\end{array}$ \\
\hline Location Quality & $\begin{array}{c}0.0873^{* *} \\
(3.06)\end{array}$ & $\begin{array}{l}0.0847 * * * \\
(4.00)\end{array}$ \\
\hline Double Section & $\begin{array}{l}0.0637 * * * \\
(5.13)\end{array}$ & $\begin{array}{l}0.0588 * * * \\
\quad(6.03)\end{array}$ \\
\hline Size (Acres) & $\begin{array}{c}0.00457 \\
(0.10)\end{array}$ & $\begin{array}{c}-0.0530 \\
(-1.48)\end{array}$ \\
\hline Median Monthly Contract Rent (county) & $\begin{array}{c}0.220^{* *} \\
(3.11)\end{array}$ & $\begin{array}{c}0.157 * * \\
(2.76)\end{array}$ \\
\hline Median Home Value (county) & $\begin{array}{c}-0.0833^{*} \\
(-2.26)\end{array}$ & $\begin{array}{l}-0.0713 \\
(-1.95)\end{array}$ \\
\hline Quality & $\begin{array}{l}0.0103 \\
(0.25)\end{array}$ & \\
\hline Condition & $\begin{array}{l}0.0191 \\
(0.47)\end{array}$ & \\
\hline Appeal & $\begin{array}{l}0.0218 \\
(0.40)\end{array}$ & \\
\hline Major Roads & & $\begin{array}{c}-0.00441 \\
(-0.50)\end{array}$ \\
\hline Hospital & & $\begin{array}{c}0.0129 \\
(0.78)\end{array}$ \\
\hline Cemeteries & & $\begin{array}{c}0.0262 \\
(1.05)\end{array}$ \\
\hline Density & & $\begin{array}{l}-0.243 \\
(-1.32)\end{array}$ \\
\hline Constant & $\begin{array}{l}1.692^{*} \\
(2.27) \\
\end{array}$ & $\begin{array}{l}0.880 \\
(1.35) \\
\end{array}$ \\
\hline \multicolumn{3}{|l|}{ Rent Income } \\
\hline Location Quality & $\begin{array}{l}0.140 * * * \\
(4.75)\end{array}$ & $\begin{array}{l}0.140 * * * \\
(4.86)\end{array}$ \\
\hline Number of Units & $\begin{array}{c}0.988 * * * \\
(26.89)\end{array}$ & $\begin{array}{c}0.989 * * * \\
(28.07)\end{array}$ \\
\hline Resident Type $\times$ Security Features & $\begin{array}{c}-0.0645 \\
(-1.82)\end{array}$ & $\begin{array}{c}-0.0684 \\
(-1.98)\end{array}$ \\
\hline Single Section & $\begin{array}{c}-0.0305 \\
(-1.96)\end{array}$ & $\begin{array}{c}-0.0305^{*} \\
(-2.03)\end{array}$ \\
\hline Double Section & $\begin{array}{l}0.0493^{* * *} \\
\quad(3.92)\end{array}$ & $\begin{array}{l}0.0498 * * * \\
\quad(4.02)\end{array}$ \\
\hline Year Built & $\begin{array}{c}-0.00484 * * \\
(-2.89)\end{array}$ & $\begin{array}{c}-0.00521^{* *} \\
(-3.12)\end{array}$ \\
\hline Security Features & $\begin{array}{c}0.0485 \\
(1.05)\end{array}$ & $\begin{array}{c}0.0512 \\
(1.16)\end{array}$ \\
\hline Project Amenities & $\begin{array}{c}0.00385 \\
(0.05)\end{array}$ & $\begin{array}{c}-0.00431 \\
(-0.05)\end{array}$ \\
\hline Median Monthly Contract Rent (county) & $\begin{array}{l}0.113 \\
(1.88)\end{array}$ & $\begin{array}{l}0.112 \\
(1.86)\end{array}$ \\
\hline Median Home Value (county) & $\begin{array}{c}0.0317 \\
(0.71)\end{array}$ & $\begin{array}{c}0.0320 \\
(0.72)\end{array}$ \\
\hline Constant & $\begin{array}{c}16.46 * * * * \\
(5.22)\end{array}$ & $\begin{array}{c}17.19 * * * \\
(5.45)\end{array}$ \\
\hline$N$ & 499 & 499 \\
\hline $\mathrm{R}^{2}$ & 0.8891 & 0.9261 \\
\hline Adjusted $\mathrm{R}^{2}$ & 0.8758 & 0.8771 \\
\hline $\begin{array}{c}t \text { statistics in parentheses } \\
* p<0.05, * * p<0.01, * * * p<0.001 \\
28\end{array}$ & & \\
\hline
\end{tabular}


Table 5: 3SLS Regression Results for Transaction Price and Rent Income as a Dependent Variables with Distance and Ratings Measures in Rental Income regression(Multiple imputed log price)

(1)

(2)

\begin{tabular}{|c|c|c|}
\hline \multicolumn{3}{|l|}{ Transaction Price } \\
\hline Rent Income & $\begin{array}{c}0.917 * * * \\
(13.78)\end{array}$ & $\begin{array}{c}1.005 * * * \\
(21.30)\end{array}$ \\
\hline Occupancy & $\begin{array}{l}0.487 \\
(2.07)\end{array}$ & $\begin{array}{c}0.867 * * * \\
(7.50)\end{array}$ \\
\hline Location Quality & $\begin{array}{c}0.107 * * * \\
(3.89)\end{array}$ & $\begin{array}{c}0.0847 * * * \\
(4.00)\end{array}$ \\
\hline Double Section & $\begin{array}{c}0.0674 * * * \\
(5.40)\end{array}$ & $\begin{array}{c}0.0588 \text { *** } \\
(6.03)\end{array}$ \\
\hline Size (Acres) & $\begin{array}{l}0.0130 \\
(0.30)\end{array}$ & $\begin{array}{c}-0.0530 \\
(-1.48)\end{array}$ \\
\hline Median Monthly Contract Rent (county) & $\begin{array}{c}0.225^{* *} \\
(3.16)\end{array}$ & $\begin{array}{c}0.157 * * \\
(2.76)\end{array}$ \\
\hline Median Home Value (county) & $\begin{array}{c}-0.0855^{*} \\
(-2.31)\end{array}$ & $\begin{array}{c}-0.0713 \\
(-1.95)\end{array}$ \\
\hline Roads & & $\begin{array}{c}-0.00441 \\
(-0.50)\end{array}$ \\
\hline Hospital & & $\begin{array}{c}0.0129 \\
(0.78)\end{array}$ \\
\hline Cemeteries & & $\begin{array}{c}0.0262 \\
(1.05)\end{array}$ \\
\hline Density & & $\begin{array}{l}-0.243 \\
(-1.32)\end{array}$ \\
\hline Constant & $\begin{array}{l}1.707^{*} \\
(2.30) \\
\end{array}$ & $\begin{array}{l}0.880 \\
(1.35) \\
\end{array}$ \\
\hline Rent Income & & \\
\hline Location Quality & $\begin{array}{c}0.142 * * * \\
(4.83)\end{array}$ & $\begin{array}{c}0.140 * * * \\
(4.86)\end{array}$ \\
\hline Number of Units & $\begin{array}{c}0.987 * * * \\
(27.80)\end{array}$ & $\begin{array}{c}0.989 * * * \\
(28.07)\end{array}$ \\
\hline Resident Type $\times$ Security Features & $\begin{array}{c}-0.0684 \\
(-1.81)\end{array}$ & $\begin{array}{c}-0.0684 \\
(-1.98)\end{array}$ \\
\hline Single Section & $\begin{array}{c}-0.0291 \\
(-1.87)\end{array}$ & $\begin{array}{c}-0.0305^{*} \\
(-2.03)\end{array}$ \\
\hline Double Section & $\begin{array}{c}0.0505^{* * * *} \\
(3.95)\end{array}$ & $\begin{array}{c}0.0498^{* * * *} \\
(4.02)\end{array}$ \\
\hline Year Built & $\begin{array}{c}-0.00503 * * \\
(-2.88)\end{array}$ & $\begin{array}{c}-0.00521 * * \\
(-3.12)\end{array}$ \\
\hline Security Features & $\begin{array}{c}0.0496 \\
(1.06)\end{array}$ & $\begin{array}{c}0.0512 \\
(1.16)\end{array}$ \\
\hline Project Amenities & $\begin{array}{c}0.00125 \\
(0.01)\end{array}$ & $\begin{array}{c}-0.00431 \\
(-0.05)\end{array}$ \\
\hline Median Monthly Contract Rent (county) & $\begin{array}{l}0.118 \\
(1.91)\end{array}$ & $\begin{array}{l}0.112 \\
(1.86)\end{array}$ \\
\hline Median Home Value (county) & $\begin{array}{l}0.0288 \\
(0.64)\end{array}$ & $\begin{array}{c}0.0320 \\
(0.72)\end{array}$ \\
\hline Quality & $\begin{array}{l}0.0337 \\
(0.73)\end{array}$ & \\
\hline Condition & $\begin{array}{c}-0.0307 \\
(-0.68)\end{array}$ & \\
\hline Appeal & $\begin{array}{c}-0.00500 \\
(-0.08)\end{array}$ & \\
\hline Constant & $\begin{array}{c}16.84 * * * \\
(5.10)\end{array}$ & $\begin{array}{c}17.19 * * * \\
(5.45)\end{array}$ \\
\hline$N$ & 499 & 499 \\
\hline $\mathrm{R}^{2}$ & 0.8876 & 0.8872 \\
\hline Adjusted $\mathrm{R}^{2}$ & 0.8761 & 0.8848 \\
\hline
\end{tabular}


negative feature - in essence, it is a measure of remoteness) also prove to be insignificant. Investors should not be concerned with the distance of these factors if the property is generating revenue. In addition, all socioeconomic variables that we tried also are insignificant.

These variables are measured at the county level, and it is hardly surprising that investors are uninterested in county education level. However, the insignificance of unemployment rate, median household income, and poverty rate is less obvious. MHC residence and $\mathrm{MH}$ unit ownership most likely has a very low or negative income elasticity as soon as a community rises above abject poverty levels, so that greater prosperity is a mixed blessing from a community investor's perspective. Added to the complexity is the heterogeneity of parks: some aim at low-income homeowners; others have a more middle-class clientele. When looking at MHC park valuation as a whole, it appears that local prosperity measures to not have a clear effect.

Let us now turn to the determinants of rental income in Tables 3 and 4. Most obviously, the number of units matters: income rises equi-proportionately. Location quality is also highly significant - note that it both drives up rents and has an additional positive effect on MHC sales price. A simple interpretation is that good locations will be increasingly scarce as populations and economies grow, so that not only do they mean higher current rents; they also mean higher expected rent growth. The number of double-wides has a similarly positive effect on both rent and sales price, and likely for similar reasons. The number of single-wides does not affect transaction price, but does have a weakly negative effect on rental income,

Amenities, while typically seen as attractive incentives for gaining more tenants, are insignificant in determining both rent and, in unreported regressions, transaction price. Regarding MHC price, a reasonable interpretation is that the more amenities a communities has, the more money the investor must spend to maintain those amenities. Other than luxury retirement communities in Florida and California, most of the manufactured home community buyers in our data set seem to prefer schools, location quality, and plentiful neighbors (occupancy). Regarding the impact on rents, it is likely that the California and Florida fixed effect terms in our regressions absorb much of the variance in amenities, and the remaining variance is likely correlated with other terms (notably, double-wides).

We pay particular attention to security features for two reasons. First, many security measures are relatively 
inexpensive as compared to, say, linking to city water, or building pools and paving streets. They are also a collective good that people may be willing to pay for. However, there also may be some residents who wish to avoid security measures, as they may run afoul of background checks or recognize that greater surveillance may crimp their own lifestyle. A natural prediction is that some parks should specialize in adequate security (and attract families, especially with children, who value these amenities) while others deliberately minimize security (and attract households that wish to go undetected or undisturbed - and may pay for the oversight).

As it turns out, security features are insignificant in both Tables 3 and 4 . However, when security features and resident type are interacted, it appears that residents of senior communities do not wish to pay for the features, and in fact value them negatively. While this may reflect the nuisance effect of additional barriers to members of a low risk community, more likely it reflects higher crime in the surrounding area, and hence a discount for living in a less safe area.

Community age has no direct effect on MHC price (in unreported regressions) but is associated with lower rental income. The effect is not huge - rents decline by about of one percent for every year a park ages. Park age surely is correlated both with unit age and a backlog of maintenance needs - indeed, we were surprised that the effect is so modest. However, these may be infrequent events: the only time community age should matter directly is when there is a prospective community with significant structural work to be done such as replacing an entire sewage field, digging new underground electricity cables, or tearing down dilapidated condemned buildings.

Finally, MHC rents rise with county median monthly rents for apartments and rental homes; home value appears unrelated to MHC rents. These findings offer further evidence in favor of the hypothesis that MHC inhabitants are choosing to live in these communities over rental housing or apartments, but are not substituting MHC housing for owner-occupied housing on owner-occupied plots. The fact that the county median rent coefficient is modest (between 0.11 and 0.13 ), coupled with the importance of county rent in the MHC sales price equation (with coefficients ranging from 0.16 to 0.22 ), suggests that MHC rents only gradually adjust to local market conditions.

Tables 5, 6, and 7 expand the transaction price and rental income equations to include several sets of dummy 
Table 6: 3SLS Regression Results for Transaction Price and Rent Income with Region and Topography Dummy Variables(Multiple imputed log price)

(1) (2)

\begin{tabular}{|c|c|c|}
\hline \multicolumn{3}{|l|}{ Transaction Price } \\
\hline Rent Income & $\begin{array}{c}0.907 * * * \\
(13.83)\end{array}$ & $\begin{array}{c}0.926^{* * * *} \\
(13.32)\end{array}$ \\
\hline Occupancy & $\begin{array}{l}0.456 \\
(1.97)\end{array}$ & $\begin{array}{l}0.464 \\
(1.96)\end{array}$ \\
\hline Location Quality & $\begin{array}{c}0.111 * * * \\
(4.03)\end{array}$ & $\begin{array}{c}0.109 * * * \\
(3.64)\end{array}$ \\
\hline Double Section & $\begin{array}{c}0.0478^{* * * *} \\
(4.31)\end{array}$ & $\begin{array}{c}0.0629 * * * \\
(4.87)\end{array}$ \\
\hline Size (Acres) & $\begin{array}{c}0.0634 \\
(1.14)\end{array}$ & $\begin{array}{c}0.00488 \\
(0.11)\end{array}$ \\
\hline Median Monthly Contract Rent (county) & $\begin{array}{c}0.187 * * \\
(2.90)\end{array}$ & $\begin{array}{c}0.205^{* *} \\
(2.83)\end{array}$ \\
\hline Median Home Value (county) & $\begin{array}{c}-0.0809^{*} \\
(-2.23)\end{array}$ & $\begin{array}{l}-0.0720 \\
(-1.90)\end{array}$ \\
\hline Region: Midwest & $\begin{array}{l}-0.151^{*} \\
(-2.19)\end{array}$ & \\
\hline Region: South & $\begin{array}{l}0.0341 \\
(0.49)\end{array}$ & \\
\hline Region: West & $\begin{array}{l}0.149 \\
(1.79)\end{array}$ & \\
\hline Topography: Level & & $\begin{array}{l}-0.105 \\
(-0.80)\end{array}$ \\
\hline Topography: Sloping & & $\begin{array}{l}-0.0382 \\
(-0.26)\end{array}$ \\
\hline Topography: Rolling & & $\begin{array}{l}-0.162 \\
(-0.98)\end{array}$ \\
\hline Topography: Hilly & & $\begin{array}{l}-0.355 \\
(-0.96)\end{array}$ \\
\hline Constant & $\begin{array}{l}1.910^{*} \\
(2.71) \\
\end{array}$ & $\begin{array}{l}1.719^{*} \\
(2.33)\end{array}$ \\
\hline Rent Income & & \\
\hline Location Quality & $\begin{array}{c}0.168 * * * \\
(6.09)\end{array}$ & $\begin{array}{c}0.143^{* * * *} \\
(4.80)\end{array}$ \\
\hline Number of Units & $\begin{array}{c}1.050 * * * \\
(29.84)\end{array}$ & $\begin{array}{c}0.991 * * * \\
(26.78)\end{array}$ \\
\hline Resident Type $\times$ Security Features & $\begin{array}{c}-0.0627 \\
(-1.67)\end{array}$ & $\begin{array}{c}-0.0620 \\
(-1.67)\end{array}$ \\
\hline Single Section & $\begin{array}{c}-0.0610 * * * \\
(-4.48)\end{array}$ & $\begin{array}{l}-0.0316 \\
(-1.96)\end{array}$ \\
\hline Year Built & $\begin{array}{c}-0.00588^{* *} * \\
(-3.35)\end{array}$ & $\begin{array}{c}-0.00529 * * \\
(-2.97)\end{array}$ \\
\hline Security Features & $\begin{array}{l}0.0383 \\
(0.83)\end{array}$ & $\begin{array}{l}0.0465 \\
(1.02)\end{array}$ \\
\hline Project Amenities & $\begin{array}{c}0.0149 \\
(0.16)\end{array}$ & $\begin{array}{c}0.00399 \\
(0.05)\end{array}$ \\
\hline Double Section & & $\begin{array}{c}0.0458^{* *} \\
(3.34)\end{array}$ \\
\hline Median Monthly Contract Rent (county) & & $\begin{array}{l}0.106 \\
(1.74)\end{array}$ \\
\hline Median Home Value (county) & & $\begin{array}{c}0.0360 \\
(0.76)\end{array}$ \\
\hline Constant & $\begin{array}{c}19.47 * * * \\
(5.73) \\
\end{array}$ & $\begin{array}{c}17.34 * * * * \\
(5.03) \\
\end{array}$ \\
\hline$N$ & 499 & 442 \\
\hline $\mathrm{R}^{2}$ & 0.9185 & 0.9118 \\
\hline Adjusted $\mathrm{R}^{2}$ & 0.8625 & 0.8774 \\
\hline $\begin{array}{c}t \text { statistics in parentheses } \\
* p<0.05, * * p<0.01, * * * p<0.001 \\
32\end{array}$ & & \\
\hline
\end{tabular}


variables. Overall, with some notable exceptions, these binary variables are generally insignificant.

Regional dummies do have an impact, with sales prices being lower in the Midwest than elsewhere. It seems that a manufactured home community in the Midwest can decrease rental income by $-22.7 \%$. This is not surprising, as land and housing in the Midwest is plentiful and cheap with several comparable alternatives to living in a manufactured home community. Inexpensive land and housing in turn reflects low population growth, or actual decline, in many Midwestern towns and cities, especially relative to the south and west.

We have also run regressions placing region and topography dummies in the rental equation. Those regressions have similar impacts as when we place them in the transaction price equation. Topography is generally insignificant. One would expect topographic features to matter mainly when investors are planning expand and build upon the property, and this is usually not the case.

Table 7 adds indicators of the nature of transaction status and rights transferred. Various forms of transaction status do not matter. Interestingly, having a leased fee is actually valued - sales price increases by nearly 40 percent. The likely reason is that leased fee indicates a relatively upscale community with stable, long-term leases.

Table 8 and 9 give a more detailed look at the value of a range of utilities. Briefly, none of the utilities' package options affected sales value - presumably because a prospective new owner could change arrangements if the current one was regarded as unprofitable. By and large, whether or not utilities are provided or there are city services should not matter greatly, since the primary objective is likely to be cost recovery, other than in the case of water and sewage, when it will depend on access to the local city system. Even more surprising is the lack of statistical significant of the utility measure on rents, though the coefficients are of expected sign, and do rise as additional utilities are provided. By implication, a park owners must provide basic amenities and might as well do so in a cost-minimizing way, since improved utilities will raise neither income flows nor park values. 
Table 7: 3SLS Regression Results for Transaction Price and Rent Income with Rights Transferred and Transaction Status Dummy Variables(Multiple imputed log price)

(1) (2)

\begin{tabular}{|c|c|c|}
\hline \multicolumn{3}{|l|}{ Transaction Price } \\
\hline Rent Income & $\begin{array}{c}0.963 * * * \\
(25.84)\end{array}$ & $\begin{array}{c}0.914 * * * \\
(12.98)\end{array}$ \\
\hline Occupancy & $\begin{array}{c}0.833 * * * \\
(7.81)\end{array}$ & $\begin{array}{l}0.479 \\
(2.04)\end{array}$ \\
\hline Location Quality & $\begin{array}{c}0.0871 * * * \\
(4.03)\end{array}$ & $\begin{array}{c}0.108 * * * \\
(3.90)\end{array}$ \\
\hline Double Section & $\begin{array}{c}0.0658^{* * * *} \\
(6.99)\end{array}$ & $\begin{array}{c}0.0693 * * * \\
(5.40)\end{array}$ \\
\hline Size (Acres) & $\begin{array}{c}-0.0166 \\
(-0.58)\end{array}$ & $\begin{array}{c}0.0142 \\
(0.31)\end{array}$ \\
\hline Median Monthly Contract Rent (county) & $\begin{array}{c}0.181 * * \\
(3.21)\end{array}$ & $\begin{array}{c}0.233 * * \\
(3.23)\end{array}$ \\
\hline Median Home Value (county) & $\begin{array}{c}-0.0842^{*} \\
(-2.08)\end{array}$ & $\begin{array}{c}-0.0919 * \\
(-2.45)\end{array}$ \\
\hline Rights Transferred: Fee Simple & $\begin{array}{l}0.271 \\
(1.47)\end{array}$ & \\
\hline Rights Transferred: Leased Fee & $\begin{array}{c}0.398^{*} \\
(1.98)\end{array}$ & \\
\hline Transaction Status: Fellow Out of Escrow & & $\begin{array}{l}-0.116 \\
(-0.57)\end{array}$ \\
\hline Transaction Status: In Contract & & $\begin{array}{c}0.0225 \\
(0.09)\end{array}$ \\
\hline Transaction Status: Listing & & $\begin{array}{l}-0.117 \\
(-0.55)\end{array}$ \\
\hline Transaction Status: Offer/Pending & & $\begin{array}{c}0.0435 \\
(0.20)\end{array}$ \\
\hline Constant & $\begin{array}{l}0.948 \\
(1.73) \\
\end{array}$ & $\begin{array}{l}1.874 * \\
(2.23) \\
\end{array}$ \\
\hline Rent Income & & \\
\hline Location Quality & $\begin{array}{c}0.131 * * * \\
(5.02)\end{array}$ & $\begin{array}{c}0.140 * * * \\
(4.60)\end{array}$ \\
\hline Number of Units & $\begin{array}{c}0.987 * * * \\
(29.13)\end{array}$ & $\begin{array}{c}0.987 * * * \\
(27.07)\end{array}$ \\
\hline Resident Type $\times$ Security Features & $\begin{array}{c}-0.0758 * * \\
(-2.82)\end{array}$ & $\begin{array}{c}-0.0660 \\
(-1.88)\end{array}$ \\
\hline Single Section & $\begin{array}{c}-0.0306^{*} \\
(-2.08)\end{array}$ & $\begin{array}{c}-0.0286 \\
(-1.80)\end{array}$ \\
\hline Double Section & $\begin{array}{c}0.0577 * * * \\
(4.83)\end{array}$ & $\begin{array}{c}0.0497 * * * \\
(3.98)\end{array}$ \\
\hline Median Monthly Contract Rent (county) & $\begin{array}{l}0.108 \\
(1.66)\end{array}$ & $\begin{array}{l}0.113 \\
(1.84)\end{array}$ \\
\hline Median Home Value (county) & $\begin{array}{c}0.0449 \\
(1.01)\end{array}$ & $\begin{array}{c}0.0305 \\
(0.70)\end{array}$ \\
\hline Year Built & $\begin{array}{c}-0.00463 * * \\
(-2.97)\end{array}$ & $\begin{array}{c}-0.00483 * \\
(-2.78)\end{array}$ \\
\hline Security Features & $\begin{array}{l}0.0396 \\
(1.36)\end{array}$ & $\begin{array}{c}0.0488 \\
(1.05)\end{array}$ \\
\hline Project Amenities & $\begin{array}{c}0.00569 \\
(0.08)\end{array}$ & $\begin{array}{c}0.00434 \\
(0.05)\end{array}$ \\
\hline Constant & $\begin{array}{c}15.94 * * * \\
(5.23)\end{array}$ & $\begin{array}{c}16.45^{* * * *} \\
(5.00) \\
\end{array}$ \\
\hline$N$ & 425 & 492 \\
\hline $\mathrm{R}^{2}$ & 0.9304 & 0.9109 \\
\hline Adjusted $\mathrm{R}^{2}$ & 0.8868 & 0.8752 \\
\hline
\end{tabular}


Table 8: 3SLS Regression Results for Transaction Price and Rent Income with Utility Dummy Variables in Transaction Price Equation(Multiple imputed log price)

(3SLS)

\begin{tabular}{|c|c|}
\hline \multicolumn{2}{|l|}{ Transaction Price } \\
\hline Rent Income & $\begin{array}{c}0.913 * * * \\
(18.22)\end{array}$ \\
\hline Occupancy & $\begin{array}{l}0.690^{* * * *} \\
(3.99)\end{array}$ \\
\hline Location Quality & $\begin{array}{l}0.107 * * * \\
(3.98)\end{array}$ \\
\hline Double Section & $\begin{array}{l}0.0409 * * \\
(3.16)\end{array}$ \\
\hline Size (Acres) & $\begin{array}{c}-0.00298 \\
(-0.08)\end{array}$ \\
\hline Median Monthly Contract Rent (county) & $\begin{array}{l}0.139 \\
(1.83)\end{array}$ \\
\hline Median Home Value (county) & $\begin{array}{l}-0.0662 \\
(-1.25)\end{array}$ \\
\hline Utilities: Water & $\begin{array}{l}0.167 \\
(0.57)\end{array}$ \\
\hline Utilities: Sewer & $\begin{array}{l}0.301 \\
(1.27)\end{array}$ \\
\hline Utilities: Trash & $\begin{array}{c}0.0979 \\
(0.46)\end{array}$ \\
\hline Utilities: A combination of two of cable, sewer, trash, or water & $\begin{array}{l}0.101 \\
(0.47)\end{array}$ \\
\hline Utilities: Water, Sewer, and Trash & $\begin{array}{c}-0.0376 \\
(-0.18)\end{array}$ \\
\hline Utilities: Water, Sewer, Trash, and Cable & $\begin{array}{c}0.0789 \\
(0.33)\end{array}$ \\
\hline Constant & $\begin{array}{l}1.964^{*} \\
(2.62) \\
\end{array}$ \\
\hline \multicolumn{2}{|l|}{ Rent Income } \\
\hline Location Quality & $\begin{array}{l}0.165^{* * * *} \\
(5.16)\end{array}$ \\
\hline Number of Units & $\begin{array}{c}1.012 * * * \\
(24.23)\end{array}$ \\
\hline Resident Type $\times$ Security Features & $\begin{array}{c}-0.0723^{*} \\
(-2.05)\end{array}$ \\
\hline Single Section & $\begin{array}{c}-0.0394^{*} \\
(-2.16)\end{array}$ \\
\hline Double Section & $\begin{array}{c}0.0433^{*} \\
(2.51)\end{array}$ \\
\hline Median Monthly Contract Rent (county) & $\begin{array}{l}0.0486 \\
(0.46)\end{array}$ \\
\hline Median Home Value (county) & $\begin{array}{l}0.0191 \\
(0.26)\end{array}$ \\
\hline Year Built & $\begin{array}{c}-0.00458^{*} \\
(-2.03)\end{array}$ \\
\hline Security Features & $\begin{array}{c}0.0123 \\
(0.33)\end{array}$ \\
\hline Project Amenities & $\begin{array}{c}-0.0344 \\
(-0.45)\end{array}$ \\
\hline Constant & $\begin{array}{c}16.47^{* * * *} \\
(3.68) \\
\end{array}$ \\
\hline$N$ & 194 \\
\hline $\mathrm{R}^{2}$ & 0.9335 \\
\hline Adjusted $\mathrm{R}^{2}$ & 0.8969 \\
\hline
\end{tabular}


Table 9: 3SLS Regression Results for Transaction Price and Rent Income with Utility Dummy Variables in Rent Equation(Multiple imputed log price)

(3SLS)

\begin{tabular}{|c|c|}
\hline \multicolumn{2}{|l|}{ Transaction Price } \\
\hline Rent Income & $\begin{array}{c}0.938 * * * \\
(18.51)\end{array}$ \\
\hline Occupancy & $\begin{array}{l}0.747 * * * \\
(5.49)\end{array}$ \\
\hline Location Quality & $\begin{array}{l}0.106^{* * * *} \\
(3.85)\end{array}$ \\
\hline Double Section & $\begin{array}{c}0.0442 * * * \\
(3.34)\end{array}$ \\
\hline Size (Acres) & $\begin{array}{c}-0.0182 \\
(-0.48)\end{array}$ \\
\hline Median Monthly Contract Rent (county) & $\begin{array}{l}0.0875 \\
(1.13)\end{array}$ \\
\hline Median Home Value (county) & $\begin{array}{c}-0.00880 \\
(-0.17)\end{array}$ \\
\hline Constant & $\begin{array}{l}1.307 \\
(1.95) \\
\end{array}$ \\
\hline Rent Income & \\
\hline Location Quality & $\begin{array}{l}0.164 * * * \\
(5.55)\end{array}$ \\
\hline Number of Units & $\begin{array}{c}0.999 * * * \\
(22.93)\end{array}$ \\
\hline Resident Type $\times$ Security Features & $\begin{array}{l}-0.0697 \\
(-1.83)\end{array}$ \\
\hline Single Section & $\begin{array}{c}-0.0318 \\
(-1.55)\end{array}$ \\
\hline Double Section & $\begin{array}{l}0.0456^{* *} \\
(2.72)\end{array}$ \\
\hline Median Monthly Contract Rent (county) & $\begin{array}{c}0.0769 \\
(0.79)\end{array}$ \\
\hline Median Home Value (county) & $\begin{array}{c}-0.00498 \\
(-0.07)\end{array}$ \\
\hline Year Built & $\begin{array}{c}-0.00465^{*} \\
(-2.09)\end{array}$ \\
\hline Security Features & $\begin{array}{c}0.0223 \\
(0.72)\end{array}$ \\
\hline Project Amenities & $\begin{array}{l}-0.0413 \\
(-0.50)\end{array}$ \\
\hline Utilities: Water & $\begin{array}{l}0.566 \\
(1.68)\end{array}$ \\
\hline Utilities: Sewer & $\begin{array}{l}0.281 \\
(1.00)\end{array}$ \\
\hline Utilities: Trash & $\begin{array}{l}0.267 \\
(1.06)\end{array}$ \\
\hline Utilities: A combination of two of cable, sewer, trash, or water & $\begin{array}{l}0.189 \\
(0.73)\end{array}$ \\
\hline Utilities: Water, Sewer, and Trash & $\begin{array}{l}0.227 \\
(0.90)\end{array}$ \\
\hline Utilities: Water, Sewer, Trash, and Cable & $\begin{array}{l}0.405 \\
(1.39)\end{array}$ \\
\hline Constant & $\begin{array}{c}16.50 * * * \\
(3.70) \\
\end{array}$ \\
\hline$N$ & 194 \\
\hline $\mathrm{R}^{2}$ & 0.9279 \\
\hline Adjusted $\mathrm{R}^{2}$ & 0.9013 \\
\hline
\end{tabular}




\subsection{Corporate Behavior in a Diverse Marketplace}

The Colliers dataset also allows us to explore supply side marketplace behavior for both small buyers and large firms. We distinguish small and local owners ("mom-and-pops") from corporate owners and purchasers by using a dummy variable that indicates whether the buyer/seller was a business or an individual through indication of business status structure. A positive "corporate" value indicates that the buyer/seller is a business. This term does not distinguish between large and small firms.

As Table 10 shows, when we include corporate to corporate sales, corporate buyers tend to pay about $15.4 \%$ more than the price that non-corporate buyers would pay. In contrast, corporate buyers pay about 10 percent less for MHCs being sold by non-corporate sellers. Corporate sellers also receive a higher price, but this is due almost entirely to higher prices paid by corporate buyers. A reasonable interpretation of these patterns is that corporate sellers make fewer forced sales while corporate buyers more effectively prowl for good opportunities. The corporate-to-corporate premium may reflect higher unobserved park quality and also more effective seller liability in the event of an undisclosed negative feature that shows up after the sale.

A corporation looking for investment vehicles is able to choose investments independent of location. If it finds the terms or price disagreeable, it can simply choose to find another community. A smaller mom-and-pop operation has less purchasing power and flexibility. In addition, due to economies of scale, corporate buyers can maintain better managed and maintained communities, as is evidenced by the premium on transaction price enjoyed by corporate sellers. In sum, both corporate buyers and sellers have considerable advantages over their less professional counterparts. The effect is picked up entirely by the corporate/non-corporate effect: an additional “small and local owner" dummy variable has no effect.

Tables 11 and 12 focus on corporate ownership's effect on rents. Most strikingly, corporate buyers acquire MHCs where rents are low-presumably because they see an opportunity to raise them. However, corporate sellers are not associated with low rents. Our interpretation is that corporate buyers hunt for underpriced parks, or ones generating less than potential revenues, but that there is not a systematic pricing difference between efficient corporate and non-corporate owners.

When residual terms are graphed, we find that in both rental income and transaction price, both sets of errors 
appeared to be normally distributed with no evidence of heteroskedasicity. The few large outliers revealed were due to portfolio sales and large sales transactions.

Given these large differences in sales prices, one might reasonably wonder whether the MHC market holds much future for non-corporate mom-and-pop outfits. For better or worse, we anticipate the increased corporatization of the manufactured housing community industry. 
Table 10: 3SLS Regression Results for Transaction Price and Rent Income with Corporate Dummy Variables in the Transaction Price Equation(Multiple imputed log price)

\begin{tabular}{|c|c|c|c|}
\hline & (1) & $(2)$ & \\
\hline \multicolumn{4}{|l|}{ Transaction Price } \\
\hline Rent Income & $\begin{array}{c}0.914 * * * \\
(14.81)\end{array}$ & $\begin{array}{c}0.924 * * * \\
(15.28)\end{array}$ & $\begin{array}{c}0.919 * * * \\
(15.19)\end{array}$ \\
\hline Occupancy & $\begin{array}{l}0.192 \\
(0.74)\end{array}$ & $\begin{array}{l}0.192 \\
(0.75)\end{array}$ & $\begin{array}{l}0.198 \\
(0.77)\end{array}$ \\
\hline Location Quality & $\begin{array}{c}0.115^{* * * *} \\
(4.26)\end{array}$ & $\begin{array}{l}0.115^{* * * *} \\
(4.24)\end{array}$ & $\begin{array}{c}0.116 * * * \\
(4.27)\end{array}$ \\
\hline Double Section & $\begin{array}{c}0.0673^{* * * *} \\
(5.53)\end{array}$ & $\begin{array}{c}0.0660 * * * \\
(5.52)\end{array}$ & $\begin{array}{c}0.0669 * * * \\
(5.56)\end{array}$ \\
\hline Size (Acres) & $\begin{array}{c}0.00592 \\
(0.15)\end{array}$ & $\begin{array}{c}0.0189 \\
(0.40)\end{array}$ & $\begin{array}{r}0.0197 \\
(0.42)\end{array}$ \\
\hline Median Monthly Contract Rent (county) & $\begin{array}{c}0.228^{* * * *} \\
(3.45)\end{array}$ & $\begin{array}{c}0.224 * * \\
(3.43)\end{array}$ & $\begin{array}{c}0.223^{* *} \\
(3.41)\end{array}$ \\
\hline Median Home Value (county) & $\begin{array}{c}-0.0908^{*} \\
(-2.44)\end{array}$ & $\begin{array}{c}-0.0855^{*} \\
(-2.27)\end{array}$ & $\begin{array}{c}-0.0863^{*} \\
(-2.30)\end{array}$ \\
\hline Corporate (buyers) & $\begin{array}{c}-0.0440 \\
(-1.12)\end{array}$ & $\begin{array}{l}-0.101 * \\
(-2.06)\end{array}$ & $\begin{array}{l}-0.0479 \\
(-1.20)\end{array}$ \\
\hline Corporate (seller) & $\begin{array}{c}0.128 * * \\
(2.94)\end{array}$ & $\begin{array}{c}0.0469 \\
(0.83)\end{array}$ & $\begin{array}{c}0.127 * * \\
(2.93)\end{array}$ \\
\hline Corporate buyers to sellers (v.v.) & & $\begin{array}{c}0.154 * \\
(2.06)\end{array}$ & \\
\hline Small \& Local Owners & & $\begin{array}{c}0.0563 \\
(0.86)\end{array}$ & $\begin{array}{c}0.0529 \\
(0.80)\end{array}$ \\
\hline Constant & $\begin{array}{c}2.023 * \\
(2.71)\end{array}$ & $\begin{array}{l}1.802^{*} \\
(2.42)\end{array}$ & $\begin{array}{l}1.863 * \\
(2.51)\end{array}$ \\
\hline \multicolumn{4}{|l|}{ Rent Income } \\
\hline Location Quality & $\begin{array}{c}0.144 * * * \\
(6.06)\end{array}$ & $\begin{array}{c}0.144 * * * \\
(6.07)\end{array}$ & $\begin{array}{c}0.144 * * * \\
(6.06)\end{array}$ \\
\hline Number of Units & $\begin{array}{c}0.983 * * * \\
(25.86)\end{array}$ & $\begin{array}{c}0.983 * * * \\
(25.86)\end{array}$ & $\begin{array}{c}0.983 * * * \\
(25.91)\end{array}$ \\
\hline Resident Type $\times$ Security Features & $\begin{array}{c}-0.0822 * \\
(-2.60)\end{array}$ & $\begin{array}{c}-0.0824 * \\
(-2.60)\end{array}$ & $\begin{array}{c}-0.0818^{*} \\
(-2.58)\end{array}$ \\
\hline Single Section & $\begin{array}{c}-0.0288 \\
(-1.88)\end{array}$ & $\begin{array}{c}-0.0289 \\
(-1.89)\end{array}$ & $\begin{array}{c}-0.0288 \\
(-1.88)\end{array}$ \\
\hline Double Section & $\begin{array}{c}0.0505 * * * \\
(4.01)\end{array}$ & $\begin{array}{c}0.0504 * * * \\
(4.00)\end{array}$ & $\begin{array}{c}0.0505 * * * \\
(4.01)\end{array}$ \\
\hline Year Built & $\begin{array}{c}-0.00482 * \\
(-2.81)\end{array}$ & $\begin{array}{c}-0.00482 * * \\
(-2.83)\end{array}$ & $\begin{array}{c}-0.00484 * * \\
(-2.83)\end{array}$ \\
\hline Security Features & $\begin{array}{c}0.0500 \\
(1.56)\end{array}$ & $\begin{array}{c}0.0504 \\
(1.57)\end{array}$ & $\begin{array}{c}0.0500 \\
(1.56)\end{array}$ \\
\hline Project Amenities & $\begin{array}{c}0.00224 \\
(0.03)\end{array}$ & $\begin{array}{c}0.00387 \\
(0.05)\end{array}$ & $\begin{array}{c}0.00254 \\
(0.03)\end{array}$ \\
\hline Median Monthly Contract Rent (county) & $\begin{array}{l}0.125 \\
(1.76)\end{array}$ & $\begin{array}{l}0.125 \\
(1.76)\end{array}$ & $\begin{array}{l}0.125 \\
(1.76)\end{array}$ \\
\hline Median Home Value (county) & $\begin{array}{c}0.0218 \\
(0.48)\end{array}$ & $\begin{array}{c}0.0219 \\
(0.48)\end{array}$ & $\begin{array}{c}0.0219 \\
(0.48)\end{array}$ \\
\hline Constant & $\begin{array}{c}16.46^{* * * *} \\
(4.88)\end{array}$ & $\begin{array}{c}16.47 * * * \\
(4.91)\end{array}$ & $\begin{array}{c}16.51 * * * \\
(4.92)\end{array}$ \\
\hline$N$ & 499 & 499 & 499 \\
\hline $\mathrm{R}^{2}$ & 0.9112 & 0.9127 & 0.9117 \\
\hline Adjusted $\mathrm{R}^{2}$ & 0.8744 & 0.8744 & 0.8744 \\
\hline
\end{tabular}


Table 11: 3SLS Regression Results for Transaction Price and Rent Income with Corporate Dummy Variables in the Rental Income Equation(Multiple imputed log price)

\begin{tabular}{|c|c|c|c|}
\hline & (1) & (2) & \\
\hline \multicolumn{4}{|l|}{ Transaction Price } \\
\hline Rent Income & $\begin{array}{c}0.920 * * * \\
(13.39)\end{array}$ & $\begin{array}{c}0.924 * * * \\
(13.13)\end{array}$ & $\begin{array}{c}0.921 * * * \\
(13.18)\end{array}$ \\
\hline Occupancy & $\begin{array}{l}0.488 \\
(2.07)\end{array}$ & $\begin{array}{l}0.487 \\
(2.07)\end{array}$ & $\begin{array}{l}0.487 \\
(2.07)\end{array}$ \\
\hline Location Quality & $\begin{array}{c}0.106^{* * * *} \\
(3.84)\end{array}$ & $\begin{array}{c}0.106 * * * \\
(3.80)\end{array}$ & $\begin{array}{c}0.106^{* * * *} \\
(3.82)\end{array}$ \\
\hline Double Section & $\begin{array}{c}0.0670 * * * \\
(5.30)\end{array}$ & $\begin{array}{c}0.0667 * * * \\
(5.23)\end{array}$ & $\begin{array}{c}0.0670 * * * \\
(5.28)\end{array}$ \\
\hline Size (Acres) & $\begin{array}{c}0.0114 \\
(0.25)\end{array}$ & $\begin{array}{c}0.00920 \\
(0.20)\end{array}$ & $\begin{array}{c}0.0109 \\
(0.24)\end{array}$ \\
\hline Median Monthly Contract Rent (county) & $\begin{array}{c}0.224 * * \\
(3.11)\end{array}$ & $\begin{array}{c}0.222 * * \\
(3.08)\end{array}$ & $\begin{array}{c}0.223 * * \\
(3.10)\end{array}$ \\
\hline Median Home Value (county) & $\begin{array}{c}-0.0851 * \\
(-2.30)\end{array}$ & $\begin{array}{c}-0.0847 * \\
(-2.29)\end{array}$ & $\begin{array}{c}-0.0850 * \\
(-2.29)\end{array}$ \\
\hline Constant & $\begin{array}{l}1.673^{*} \\
(2.22)\end{array}$ & $\begin{array}{l}1.643^{*} \\
(2.15)\end{array}$ & $\begin{array}{l}1.672 * \\
(2.20)\end{array}$ \\
\hline \multicolumn{4}{|l|}{ Rent Income } \\
\hline Location Quality & $\begin{array}{c}0.136 * * * \\
(4.74)\end{array}$ & $\begin{array}{c}0.137 * * * \\
(4.67)\end{array}$ & $\begin{array}{c}0.137 * * * \\
(4.70)\end{array}$ \\
\hline Number of Units & $\begin{array}{c}0.993 * * * \\
(28.05)\end{array}$ & $\begin{array}{c}1.003 * * * \\
(22.90)\end{array}$ & $\begin{array}{c}1.001 * * * \\
(22.78)\end{array}$ \\
\hline Resident Type $\times$ Security Features & $\begin{array}{c}-0.0586 \\
(-1.68)\end{array}$ & $\begin{array}{c}-0.0586 \\
(-1.66)\end{array}$ & $\begin{array}{c}-0.0593 \\
(-1.70)\end{array}$ \\
\hline Single Section & $\begin{array}{c}-0.0267 \\
(-1.76)\end{array}$ & $\begin{array}{c}-0.0263 \\
(-1.74)\end{array}$ & $\begin{array}{c}-0.0266 \\
(-1.76)\end{array}$ \\
\hline Double Section & $\begin{array}{c}0.0497 * * * \\
(3.98)\end{array}$ & $\begin{array}{c}0.0496 * * * \\
(3.98)\end{array}$ & $\begin{array}{c}0.0498 * * * \\
(3.98)\end{array}$ \\
\hline Year Built & $\begin{array}{c}-0.00521 * * \\
(-3.26)\end{array}$ & $\begin{array}{c}-0.00516^{* * *} \\
(-3.29)\end{array}$ & $\begin{array}{c}-0.00511 * * \\
(-3.25)\end{array}$ \\
\hline Security Features & $\begin{array}{c}0.0511 \\
(1.15)\end{array}$ & $\begin{array}{c}0.0514 \\
(1.16)\end{array}$ & $\begin{array}{c}0.0508 \\
(1.14)\end{array}$ \\
\hline Project Amenities & $\begin{array}{c}-0.000596 \\
(-0.01)\end{array}$ & $\begin{array}{c}-0.00354 \\
(-0.05)\end{array}$ & $\begin{array}{c}-0.00175 \\
(-0.02)\end{array}$ \\
\hline Median Monthly Contract Rent (county) & $\begin{array}{c}0.118^{*} \\
(2.00)\end{array}$ & $\begin{array}{l}0.116 \\
(1.92)\end{array}$ & $\begin{array}{l}0.115 \\
(1.90)\end{array}$ \\
\hline Median Home Value (county) & $\begin{array}{c}0.0314 \\
(0.74)\end{array}$ & $\begin{array}{c}0.0345 \\
(0.80)\end{array}$ & $\begin{array}{c}0.0338 \\
(0.78)\end{array}$ \\
\hline Corporate (buyers) & $\begin{array}{l}-0.131 * \\
(-2.50)\end{array}$ & $\begin{array}{l}-0.158 * \\
(-2.42)\end{array}$ & $\begin{array}{l}-0.133 * \\
(-2.51)\end{array}$ \\
\hline Corporate (seller) & $\begin{array}{c}-0.00854 \\
(-0.14)\end{array}$ & $\begin{array}{c}-0.0452 \\
(-0.62)\end{array}$ & $\begin{array}{c}-0.00899 \\
(-0.15)\end{array}$ \\
\hline Corporate buyers to sellers (v.v.) & & $\begin{array}{c}0.0712 \\
(0.82)\end{array}$ & \\
\hline Small \& Local Owners & & $\begin{array}{c}0.0255 \\
(0.43)\end{array}$ & $\begin{array}{c}0.0232 \\
(0.39)\end{array}$ \\
\hline Constant & $\begin{array}{c}17.19 * * * \\
(5.71)\end{array}$ & $\begin{array}{c}17.00 * * * \\
(5.77)\end{array}$ & $\begin{array}{c}16.93 * * * \\
(5.71)\end{array}$ \\
\hline$N$ & 499 & 499 & 499 \\
\hline $\mathrm{R}^{2}$ & 0.9093 & 0.9095 & 0.9093 \\
\hline Adjusted $\mathrm{R}^{2}$ & 0.8788 & 0.8795 & 0.8790 \\
\hline
\end{tabular}


Table 12: 3SLS Regression Results for Transaction Price and Rent Income with Corporate Dummy Variables in Both Equations(Multiple imputed log price)

\begin{tabular}{|c|c|c|c|}
\hline & (1) & (2) & \\
\hline \multicolumn{4}{|l|}{ Transaction Price } \\
\hline Rent Income & $\begin{array}{c}0.919 * * * \\
(13.61)\end{array}$ & $\begin{array}{c}0.932 * * * \\
(14.42)\end{array}$ & $\begin{array}{c}0.926 * * * \\
(14.32)\end{array}$ \\
\hline Occupancy & $\begin{array}{l}0.480 \\
(2.05)\end{array}$ & $\begin{array}{l}0.481 \\
(2.07)\end{array}$ & $\begin{array}{l}0.486 \\
(2.10)\end{array}$ \\
\hline Location Quality & $\begin{array}{c}0.105^{* * * *} \\
(3.82)\end{array}$ & $\begin{array}{c}0.104 * * * \\
(3.77)\end{array}$ & $\begin{array}{c}0.106^{* * * *} \\
(3.80)\end{array}$ \\
\hline Double Section & $\begin{array}{c}0.0650^{* * * *} \\
(5.23)\end{array}$ & $\begin{array}{c}0.0635^{* * *} * \\
(5.19)\end{array}$ & $\begin{array}{c}0.0645 * * * \\
(5.25)\end{array}$ \\
\hline Size (Acres) & $\begin{array}{c}0.0153 \\
(0.35)\end{array}$ & $\begin{array}{l}0.0306 \\
(0.56)\end{array}$ & $\begin{array}{c}0.0310 \\
(0.57)\end{array}$ \\
\hline Median Monthly Contract Rent (county) & $\begin{array}{c}0.214 * * \\
(3.02)\end{array}$ & $\begin{array}{c}0.210^{* *} \\
(3.07)\end{array}$ & $\begin{array}{c}0.207 * * \\
(3.02)\end{array}$ \\
\hline Median Home Value (county) & $\begin{array}{c}-0.0750^{*} \\
(-2.03)\end{array}$ & $\begin{array}{c}-0.0690 \\
(-1.92)\end{array}$ & $\begin{array}{c}-0.0699 \\
(-1.92)\end{array}$ \\
\hline Corporate (buyers) & $\begin{array}{c}-0.0611 \\
(-1.60)\end{array}$ & $\begin{array}{l}-0.118^{*} \\
(-2.35)\end{array}$ & $\begin{array}{l}-0.0656 \\
(-1.66)\end{array}$ \\
\hline Corporate (seller) & $\begin{array}{c}0.121 * * \\
(2.72)\end{array}$ & $\begin{array}{c}0.0364 \\
(0.61)\end{array}$ & $\begin{array}{c}0.119 * * \\
(2.69)\end{array}$ \\
\hline Corporate buyers to sellers (v.v.) & & $\begin{array}{l}0.159 \\
(1.95)\end{array}$ & \\
\hline Small \& Local Owners & & $\begin{array}{l}0.0711 \\
(1.03)\end{array}$ & $\begin{array}{c}0.0673 \\
(0.98)\end{array}$ \\
\hline Constant & $\begin{array}{l}1.625^{*} \\
(2.18)\end{array}$ & $\begin{array}{l}1.347 \\
(1.98) \\
\end{array}$ & $\begin{array}{l}1.419 \\
(2.06) \\
\end{array}$ \\
\hline Rent Income & & & \\
\hline Location Quality & $\begin{array}{c}0.136 * * * \\
(4.72)\end{array}$ & $\begin{array}{c}0.137 * * * \\
(4.67)\end{array}$ & $\begin{array}{c}0.138 * * * \\
(4.70)\end{array}$ \\
\hline Number of Units & $\begin{array}{c}0.994 * * * \\
(28.00)\end{array}$ & $\begin{array}{c}1.009 * * * \\
(23.34)\end{array}$ & $\begin{array}{c}1.006 * * * \\
(23.24)\end{array}$ \\
\hline Resident Type $\times$ Security Features & $\begin{array}{c}-0.0584 \\
(-1.68)\end{array}$ & $\begin{array}{c}-0.0585 \\
(-1.66)\end{array}$ & $\begin{array}{c}-0.0591 \\
(-1.69)\end{array}$ \\
\hline Single Section & $\begin{array}{c}-0.0268 \\
(-1.77)\end{array}$ & $\begin{array}{c}-0.0264 \\
(-1.75)\end{array}$ & $\begin{array}{c}-0.0267 \\
(-1.77)\end{array}$ \\
\hline Double Section & $\begin{array}{c}0.0492^{* * * *} \\
(3.94)\end{array}$ & $\begin{array}{c}0.0490 * * * \\
(3.93)\end{array}$ & $\begin{array}{c}0.0492 * * * \\
(3.94)\end{array}$ \\
\hline YearBuilt & $\begin{array}{c}-0.00520 * * \\
(-3.25)\end{array}$ & $\begin{array}{c}-0.00513 * * \\
(-3.28)\end{array}$ & $\begin{array}{c}-0.00509 * * \\
(-3.23)\end{array}$ \\
\hline SecurityFeatures & $\begin{array}{c}0.0506 \\
(1.13)\end{array}$ & $\begin{array}{c}0.0508 \\
(1.14)\end{array}$ & $\begin{array}{c}0.0502 \\
(1.12)\end{array}$ \\
\hline ProjectAmenities & $\begin{array}{c}-0.000823 \\
(-0.01)\end{array}$ & $\begin{array}{c}-0.00423 \\
(-0.05)\end{array}$ & $\begin{array}{c}-0.00231 \\
(-0.03)\end{array}$ \\
\hline Median Monthly Contract Rent (county) & $\begin{array}{l}0.116 \\
(1.96)\end{array}$ & $\begin{array}{l}0.113 \\
(1.86)\end{array}$ & $\begin{array}{l}0.110 \\
(1.82)\end{array}$ \\
\hline Median Home Value (county) & $\begin{array}{l}0.0339 \\
(0.80)\end{array}$ & $\begin{array}{l}0.0384 \\
(0.89)\end{array}$ & $\begin{array}{c}0.0376 \\
(0.87)\end{array}$ \\
\hline Corporate (buyers) & $\begin{array}{c}-0.145^{* *} \\
(-3.00)\end{array}$ & $\begin{array}{c}-0.185 * * \\
(-3.14)\end{array}$ & $\begin{array}{c}-0.148^{* *} \\
(-3.05)\end{array}$ \\
\hline Corporate (seller) & $\begin{array}{c}0.0204 \\
(0.37)\end{array}$ & $\begin{array}{c}-0.0362 \\
(-0.52)\end{array}$ & $\begin{array}{c}0.0196 \\
(0.36)\end{array}$ \\
\hline Corporate buyers to sellers (v.v.) & & $\begin{array}{l}0.107 \\
(1.26)\end{array}$ & \\
\hline Small \& Local Owners & & $\begin{array}{c}0.0373 \\
(0.64)\end{array}$ & $\begin{array}{c}0.0349 \\
(0.60)\end{array}$ \\
\hline Constant & $\begin{array}{c}17.16^{* * * *} \\
(5.70) \\
\end{array}$ & $\begin{array}{c}16.90 * * * * \\
(5.73) \\
\end{array}$ & $\begin{array}{c}16.83 * * * * \\
(5.68) \\
\end{array}$ \\
\hline$N$ & 499 & 499 & 499 \\
\hline $\mathrm{R}^{2}$ & 0.9114 & 0.9131 & 0.9120 \\
\hline Adjusted $\mathrm{R}^{2}$ & 0.8789 & 0.8797 & 0.8791 \\
\hline
\end{tabular}




\section{Conclusion}

The obvious point of departure is that hedonic pricing models appear to effectively describe MHC park values, even though the housing structures tend to be owned by agents who are not party to the park sale. The second point to emerge is that local rents matter, both in determining current rents and MHP sale value; owner-occupied housing prices are not consistently significant.

This leads us to believe that rental apartments and stand-alone housing are the primary alternatives for those living in MHCs during the period 2010-14. Thus, it is misleading to compare a manufactured house to a stickbuilt house, and potential profitability will depend on a narrower segment of the housing market. Manufactured housing is instead more comparable to apartments and MHCs are comparable to other revenue-generating rental properties such as apartment complexes and commercial lease spaces. Because rental structures are indeed the alternatives to both the supply and demand side, the current pricing of these properties reflect market place opportunity costs.

A third finding is that there is considerable difference in pricing between corporate and mom-and-pop owners.

Fourth, rents do depend on location quality, and beyond general quality, on distance from schools. Rather to our surprise, while park age (likely correlated with units' age) matters, park amenities and security features do not seem to be important.

Finally, professional assessors do an excellent job of estimating MHP value (Table A3). Because of the considerable idiosyncrasies of particular parks, no sane park buyer would forgo a site-based assessment and rely exclusively on estimates generated from geo-spatial, financial, and readily-available descriptive data. At the same time, much of a park's value can be inferred from these data, and it is reassuring to know that the assessed and econometrically estimated values are highly correlated. 


\section{References}

2012 Mobile Home Market Facts. Rep. Caledonia, MI: Foremost Insurance Group, 2012. Print.

Aman, Destiny D., and Brent Yarnal. "Home Sweet Mobile Home? Benefits and Challenges of Mobile Home Ownership in Rural Pennsylvania.”Applied Geography 30.1 (2010): 84-95.

Amenyah, Ivy D., and Ernest Fletcher. "Factors Determining Residential Rental Prices.” Asian Economic and Financial Review 3.1 (2013): 39-50.

Barker, David. "Length of Residence Discounts, Turnover, and Demand Elasticity. Should Long-term Tenants Pay Less than New Tenants?'Journal of Housing Economics 12.1 (2003): 1-11.

Becker, Charles M., and Caitlin Gorback. "Trailer Park Economics: Motives for Manufactured Housing Park Residence.” Durham, NC: Duke University Department of Economics, Unpublished MS (2015).

Becker, Charles M., and Ashley Yea. ’Land Use Restrictions and Manufactured Housing Community Values.” Durham, NC: Duke University Department of Economics, Unpublished MS (2015).

Brown, John M., and Molly A. Sellman. "Manufactured Housing: The Invalidity of the "Mobility" Standard." The Urban Lawyer 19.2 (1987): 367-99.

Capozza, Dennis R., Ryan D. Israelsen, and Thomas A. Thomson. "Appraisal, Agency and Atypicality: Evidence from Manufactured Homes." Real Estate Economics 33.3 (2005): 509-37.

Case, Karl E., and Robert J. Shiller. "Is There a Bubble in the Housing Market?" Brookings Papers on Economic Activity 2003.2 (2003): 299-362.

Case, Karl E., and Robert J. Shiller. "Price of Single-family Homes since 1970: New Indexes for Four Cities.” New England Economic Review September/October (1987): 45-56.

"Freddie Mac to Purchase and Securitize Manufactured Housing Community Loans." Freddie Mac Multifamily. N.p., 30 Apr. 2014. Web. 13 July 2015. http://freddiemac.mwnewsroom.com/press-releases/freddie-mac-to-purchase-and-securitize-manufacture-otcqbfmcc-1111279.

Frew, James, and G. D. Jud. "Estimating the Value of Apartment Buildings.”Journal of Real Estate Research 25.1 (2003): 77-86. Genz, Richard. "Why Advocates Need to Rethink Manufactured Housing." Housing Policy Debate 12.2 (2001): 393-414.

Gorback, Caitlin. "Trailer Park Economics.” Duke Journal of Economics (2011).

Iwata, Shinichiro, and Hisaki Yamaga. "Rental Externality, Tenure Security, and Housing Quality.” Journal of Housing Economics 17.3 (2008): 201-11.

Jeong, Jae G., Makarand Hastak, and Matt Syal. "Supply Chain Simulation Modeling for the Manufactured Housing Industry.” Journal of Urban Planning and Development 132.4 (2006): 217-225.

Jud, G. D., John D. Benjamin, and G. S. Sirmans. "What Do We Know about Apartments and Their Markets?" The Journal of Real Estate Research 11.3 (1996): 243-57.

Kaneko, Mamoru, Tamon Ito, and Yu-Ichi Osawa. "Duality in Comparative Statics in Rental Housing Markets with Indivisibilities.” Journal of Urban Economics 59.1 (2006): 142-70.

Larsen, Erling Røed, and Dag Einar Sommervoll. "The Impact on Rent from Tenant and Landlord Characteristics and Interaction.” Regional Science and Urban Economics 39.3 (2009): 316-22.

Lee, K. J., and J. B. Carlin. "Multiple Imputation for Missing Data: Fully Conditional Specification Versus Multivariate Normal Imputation." American Journal of Epidemiology 171.5 (2010): 624-32.

Logan, John R., Zengwang Xu, and Brian Stults. 2014. "Interpolating US Decennial Census Tract Data from as Early as 1970 to 2010 : A Longitudinal Tract Database" The Professional Geographer 66(3): 412-420.

Marshall, Maria I., and Thomas L. Marsh. "Consumer and Investment Demand for Manufactured Housing Units." Journal of Housing Economics 16.1 (2007): 59-71.

"Manufactured Housing Community Loan". Freddie Mac Multifamily, January 2015: 1-2.

Mccarty, William P., and Daniel P. Hepworth. "Mobile Home Parks and Crime: Does Proximity Matter?" Journal of Crime and Justice 36.3 (2013): 319-33.

Michelon, L. C. "The New Leisure Class.” American Journal of Sociology59.4 (1954): 371.

Munneke, Henry J., and V. C. Slawson. "A Housing Price Model with Endogenous Externality Location: A Study of Mobile Home Parks." Journal of Real Estate Finance and Economics 19.2 (1999): 113-31.

Nell, Bruce, and Chuck Schierbeck, II. "Colliers International Valuation Advisory Services Manufactured Housing Survey Summary." Colliers International Q1 (2013): 1-9.

Roback, Jennifer. ’Wages, Rents, and the Quality of Life.” Journal of Political Economy 90.6 (1982): 1257.

Rosen, Sherwin. "Hedonic Prices and Implicit Markets: Product Differentiation in Pure Competition.” Journal of Political Economy 82.1 (1974): 34-55.

Rubin, Donald B. "Multiple Imputation After 18 Years." Journal of the American Statistical Association 91.434 (1996): 473.

Rubin, Donald B. Multiple Imputation for Nonresponse in Surveys. New York: Wiley, 1987.

Schafer, Joseph L., and John W. Graham. ’Missing Data: Our View of the State of the Art.” Psychological Methods 7.2 (2002): 147-77.

Shiller, Robert J. Irrational Exuberance. Princeton, NJ: Princeton University Press, 2006.

U.S. Census Bureau; 2010 Census Demographic Profiles, Summary File 1;generated by Ashley Yea; http://www.census.gov/2010census/data/; (1 January 2015).

U.S. Census Bureau; 2010 Census Demographic Profiles, Summary File 2;generated by Ashley Yea; http://www.census.gov/2010census/data/; (1 January 2015).

Vanderford, Stephanie E., Yoko Mimura, and Anne L. Sweaney. "A Hedonic Price Comparison of Manufactured and Site-Built Homes in the Non-MSA U.S.' Journal of Real Estate Research 27.1 (2005): 83-104.

Zheng, Diehang, Yongheng Deng, Peter Gordon, and David Dale-Johnson. "An Examination of the Impact of Rent Control on Mobile Home Prices in California.” Journal of Housing Economics 16.2 (2007): 209-42. 
8 Appendix 
Table A1: 3SLS Regression Results for Transaction Price and Rent Income as a Dependent Variables (nonimputed values)

\begin{tabular}{|c|c|c|c|}
\hline & (1) & (2) & (3) \\
\hline \multicolumn{4}{|l|}{ Transaction Price } \\
\hline Rent Income & $\begin{array}{l}1.019 * * * \\
(16.95)\end{array}$ & $\begin{array}{l}0.969 * * * \\
(13.44)\end{array}$ & $\begin{array}{c}0.975^{* * *} \\
(13.93)\end{array}$ \\
\hline Occupancy & $\begin{array}{l}0.985^{* * * *} \\
(5.50)\end{array}$ & $\begin{array}{l}1.845^{* * * *} \\
(6.24)\end{array}$ & $\begin{array}{l}1.763 * * * \\
(5.90)\end{array}$ \\
\hline Location Quality & $\begin{array}{l}0.0799 * * \\
(2.65)\end{array}$ & $\begin{array}{c}0.104 * * \\
(3.13)\end{array}$ & $\begin{array}{l}0.103 * * \\
(3.08)\end{array}$ \\
\hline Double Section & $\begin{array}{c}0.0344^{*} \\
(2.11)\end{array}$ & $\begin{array}{l}0.0182 \\
(1.04)\end{array}$ & $\begin{array}{c}0.0184 \\
(1.05)\end{array}$ \\
\hline Size (Acres) & $\begin{array}{l}-0.0198 \\
(-0.46)\end{array}$ & $\begin{array}{l}0.0397 \\
(0.74)\end{array}$ & $\begin{array}{c}0.0500 \\
(0.93)\end{array}$ \\
\hline Median Monthly Contract Rent (county) & & $\begin{array}{l}0.261^{*} \\
(2.56)\end{array}$ & $\begin{array}{c}0.298 * * \\
(2.88)\end{array}$ \\
\hline Median Home Value (county) & & $\begin{array}{c}-0.0483 \\
(-0.78)\end{array}$ & $\begin{array}{c}0.00288 \\
(0.04)\end{array}$ \\
\hline High School or less & & & $\begin{array}{l}0.136 \\
(1.95)\end{array}$ \\
\hline 4-Year College Degree & & & $\begin{array}{c}0.00383 \\
(0.08)\end{array}$ \\
\hline Unemployed & & & $\begin{array}{c}-0.0374 \\
(-0.67)\end{array}$ \\
\hline Median Household Income & & & $\begin{array}{l}-0.102 \\
(-0.65)\end{array}$ \\
\hline Persons in Poverty & & & $\begin{array}{l}-0.0174 \\
(-0.30)\end{array}$ \\
\hline Constant & $\begin{array}{l}0.639 \\
(0.89)\end{array}$ & $\begin{array}{l}-0.771 \\
(-0.87) \\
\end{array}$ & $\begin{array}{l}-1.254 \\
(-0.81)\end{array}$ \\
\hline \multicolumn{4}{|l|}{ Rent Income } \\
\hline Location Quality & $\begin{array}{l}0.170 * * * \\
(6.08)\end{array}$ & $\begin{array}{l}0.150 * * * \\
(4.63)\end{array}$ & $\begin{array}{c}0.150 * * * \\
(4.63)\end{array}$ \\
\hline Number of Units & $\begin{array}{c}0.993 * * * \\
(24.96)\end{array}$ & $\begin{array}{l}1.009 * * * \\
(21.13)\end{array}$ & $\begin{array}{c}1.009 * * * \\
(21.03)\end{array}$ \\
\hline Resident Type $\times$ Security Features & $\begin{array}{c}-0.0886^{* * * *} \\
(-3.48)\end{array}$ & $\begin{array}{c}-0.119 * * * \\
(-4.00)\end{array}$ & $\begin{array}{c}-0.121 * * * \\
(-4.03)\end{array}$ \\
\hline Single Section & $\begin{array}{c}-0.0271 \\
(-1.51)\end{array}$ & $\begin{array}{c}-0.0616^{* * * *} \\
(-3.30)\end{array}$ & $\begin{array}{c}-0.0639 * * * \\
(-3.37)\end{array}$ \\
\hline Double Section & $\begin{array}{c}0.0291 \\
(1.51)\end{array}$ & $\begin{array}{c}0.0112 \\
(0.57)\end{array}$ & $\begin{array}{c}0.00979 \\
(0.50)\end{array}$ \\
\hline Year Built & & $\begin{array}{c}-0.00866^{* * *} \\
(-3.23)\end{array}$ & $\begin{array}{c}-0.00849 * * \\
(-3.15)\end{array}$ \\
\hline Security Features & & $\begin{array}{l}0.0338 \\
(1.23)\end{array}$ & $\begin{array}{c}0.0344 \\
(1.24)\end{array}$ \\
\hline Project Amenities & & $\begin{array}{c}0.0473 \\
(0.69)\end{array}$ & $\begin{array}{c}0.0549 \\
(0.80)\end{array}$ \\
\hline Median Monthly Contract Rent (county) & & $\begin{array}{l}0.155 \\
(1.64)\end{array}$ & $\begin{array}{l}0.152 \\
(1.61)\end{array}$ \\
\hline Median Home Value (county) & & $\begin{array}{c}0.0978 \\
(1.59)\end{array}$ & $\begin{array}{l}0.100 \\
(1.64)\end{array}$ \\
\hline Constant & $\begin{array}{c}8.169 * * * \\
(54.25)\end{array}$ & $\begin{array}{c}23.17 * * * \\
(4.30)\end{array}$ & $\begin{array}{c}22.84 * * * \\
(4.21)\end{array}$ \\
\hline$N$ & 129 & 90 & 90 \\
\hline $\mathrm{R}^{2}$ & 0.9275 & 0.9362 & 0.9401 \\
\hline Adjusted $\mathrm{R}^{2}$ & 0.9013 & 0.9174 & 0.9174 \\
\hline
\end{tabular}


Table A2: OLS Regression Results for Occupancy as a Dependent Variable (non-imputed and imputed values)

\begin{tabular}{|c|c|c|c|c|}
\hline & (1) & (2) & (3) & (Imputed) \\
\hline Number of Units & $\begin{array}{c}-0.0862^{*} \\
(-2.08)\end{array}$ & $\begin{array}{c}-0.0833 \\
(-1.85)\end{array}$ & $\begin{array}{c}-0.0713 \\
(-1.57)\end{array}$ & $\begin{array}{c}-0.0931 \\
(-1.81)\end{array}$ \\
\hline Project Amenities & $\begin{array}{c}0.0192 \\
(0.72)\end{array}$ & $\begin{array}{c}0.0229 \\
(0.80)\end{array}$ & $\begin{array}{c}0.0224 \\
(0.78)\end{array}$ & $\begin{array}{l}0.198 \\
(2.24)\end{array}$ \\
\hline Size (Acres) & $\begin{array}{c}0.00556 \\
(0.23)\end{array}$ & $\begin{array}{c}0.00182 \\
(0.07)\end{array}$ & $\begin{array}{c}-0.0113 \\
(-0.42)\end{array}$ & $\begin{array}{c}-0.0558 \\
(-1.27)\end{array}$ \\
\hline Resident Type & $\begin{array}{c}0.0280 \\
(1.12)\end{array}$ & $\begin{array}{c}0.0268 \\
(1.01)\end{array}$ & $\begin{array}{c}0.0234 \\
(0.88)\end{array}$ & $\begin{array}{c}0.00852 \\
(0.25)\end{array}$ \\
\hline Location Quality & $\begin{array}{c}0.0174 \\
(1.54)\end{array}$ & $\begin{array}{l}0.0193 \\
(1.60)\end{array}$ & $\begin{array}{c}0.0172 \\
(1.42)\end{array}$ & $\begin{array}{c}0.0276 \\
(1.66)\end{array}$ \\
\hline Expenses & $\begin{array}{c}0.0368 \\
(1.30)\end{array}$ & $\begin{array}{l}0.0394 \\
(1.26)\end{array}$ & $\begin{array}{c}0.0371 \\
(1.18)\end{array}$ & $\begin{array}{c}0.0242 \\
(0.89)\end{array}$ \\
\hline Small \& Local Owners & $\begin{array}{c}-0.0118 \\
(-0.31)\end{array}$ & $\begin{array}{c}-0.0167 \\
(-0.40)\end{array}$ & $\begin{array}{c}-0.0328 \\
(-0.77)\end{array}$ & $\begin{array}{c}-0.0717 \\
(-1.17)\end{array}$ \\
\hline High School or less & & $\begin{array}{c}0.0248 \\
(1.05)\end{array}$ & $\begin{array}{c}0.0286 \\
(1.21)\end{array}$ & $\begin{array}{c}0.0381 \\
(1.03)\end{array}$ \\
\hline 4-Year College Degree & & $\begin{array}{l}0.0205 \\
(1.04)\end{array}$ & $\begin{array}{c}0.0235 \\
(1.15)\end{array}$ & $\begin{array}{l}0.0212 \\
(0.76)\end{array}$ \\
\hline Unemployed & & $\begin{array}{c}0.00755 \\
(0.35)\end{array}$ & $\begin{array}{c}0.00919 \\
(0.42)\end{array}$ & $\begin{array}{c}-0.0365 \\
(-1.28)\end{array}$ \\
\hline Persons in Poverty & & $\begin{array}{c}-0.0210 \\
(-0.86)\end{array}$ & $\begin{array}{c}-0.0267 \\
(-1.06)\end{array}$ & $\begin{array}{c}0.00696 \\
(0.22)\end{array}$ \\
\hline Median Household Income & & $\begin{array}{c}-0.0551 \\
(-0.95)\end{array}$ & $\begin{array}{c}-0.0701 \\
(-1.18)\end{array}$ & $\begin{array}{c}-0.0336 \\
(-0.46)\end{array}$ \\
\hline y2010 & & & $\begin{array}{l}0 \\
(.)\end{array}$ & $\begin{array}{l}0.311 \\
(1.45)\end{array}$ \\
\hline y2011 & & & $\begin{array}{l}0 \\
\text { (.) }\end{array}$ & $\begin{array}{l}0.301 \\
(1.67)\end{array}$ \\
\hline y2012 & & & $\begin{array}{c}0.0344 \\
(0.53)\end{array}$ & $\begin{array}{l}0.296 \\
(1.72)\end{array}$ \\
\hline y2013 & & & $\begin{array}{c}0.0845 \\
(1.32)\end{array}$ & $\begin{array}{l}0.293 \\
(1.72)\end{array}$ \\
\hline y2014 & & & $\begin{array}{c}0.0636 \\
(0.97)\end{array}$ & $\begin{array}{l}0.290 \\
(1.68)\end{array}$ \\
\hline Constant & $\begin{array}{c}0.801 * * * \\
(3.39)\end{array}$ & $\begin{array}{l}1.142 \\
(1.73)\end{array}$ & $\begin{array}{l}1.246 \\
(1.87) \\
\end{array}$ & $\begin{array}{l}0.899 \\
(1.07)\end{array}$ \\
\hline$N$ & 138 & 131 & 131 & 499 \\
\hline $\begin{array}{l}\mathrm{R}^{2} \\
\text { Adjusted } \mathrm{R}^{2}\end{array}$ & $\begin{array}{l}0.0997 \\
0.0512\end{array}$ & $\begin{array}{l}0.1195 \\
0.0299\end{array}$ & $\begin{array}{l}0.1492 \\
0.0382\end{array}$ & $\begin{array}{l}0.4055 \\
0.3845\end{array}$ \\
\hline
\end{tabular}


Table A3: Binary OLS Regression Results for Collier's Appraisal Price as a Dependent Variable (Appraisal Price)

\begin{tabular}{lc}
\hline Transaction Price & $\begin{array}{c}0.990 * * * \\
(81.86)\end{array}$ \\
Constant & 0.137 \\
& $(0.76)$ \\
\hline \hline$N$ & 485 \\
\hline $\mathrm{R}^{2}$ & 0.9328 \\
Adjusted $\mathrm{R}^{2}$ & 0.9326 \\
\hline \hline \multicolumn{2}{c}{$t$ statistics in parentheses } \\
$* p<0.05, * * p<0.01,{ }^{* * *} p<0.001$ &
\end{tabular}

